\title{
The SARS-CoV-2/Receptor Axis in Heart and Blood Vessels: A Crisp Update on COVID-19 Disease with Cardiovascular Complications
}

\author{
Priya Veluswamy ${ }^{1, *}$, Max Wacker $^{1}{ }^{(\mathbb{D},}$, Dimitrios Stavridis ${ }^{1}{ }^{(D)}$, Thomas Reichel ${ }^{2}$, Hendrik Schmidt ${ }^{2}$, \\ Maximilian Scherner ${ }^{1}$, Jens Wippermann ${ }^{1}$ and Guido Michels ${ }^{3}$ \\ 1 Heart Surgery Research, Department of Cardiothoracic Surgery, Faculty of Medicine, Otto-von-Guericke \\ University, 39120 Magdeburg, Germany; max.wacker@med.ovgu.de (M.W.); \\ Dimitrios.Stavridis@st.ovgu.de (D.S.); Maximilian.Scherner@med.ovgu.de (M.S.); \\ Jens.Wippermann@med.ovgu.de (J.W.) \\ 2 Department of Cardiology, Diabetology and Infectiology, Klinikum Magdeburg, 39130 Magdeburg, Germany; \\ Thomas.Reichel@Klinikum-Magdeburg.de (T.R.); Hendrik.Schmidt@Klinikum-Magdeburg.de (H.S.) \\ 3 Department of Acute and Emergency Care, Sankt Antonius-Hospital Eschweiler, 52249 Eschweiler, Germany; \\ Michels@SAH-ESCHWEILER.DE \\ * Correspondence: Priya.Veluswamy@med.ovgu.de; Tel.: +49-391-6714273
}

Citation: Veluswamy, P.; Wacker, M.; Stavridis, D.; Reichel, T.; Schmidt, H.; Scherner, M.; Wippermann, J.; Michels, G. The SARS-CoV-2/ Receptor Axis in Heart and Blood Vessels: A Crisp Update on COVID-19 Disease with Cardiovascular Complications. Viruses 2021, 13, 1346. https:// doi.org/10.3390/v13071346

Academic Editors: Oliver Schildgen and Luis Martinez-Sobrido

Received: 2 June 2021

Accepted: 6 July 2021

Published: 12 July 2021

Publisher's Note: MDPI stays neutral with regard to jurisdictional claims in published maps and institutional affiliations.

Copyright: (c) 2021 by the authors. Licensee MDPI, Basel, Switzerland. This article is an open access article distributed under the terms and conditions of the Creative Commons Attribution (CC BY) license (https:// creativecommons.org/licenses/by/ $4.0 /)$.
Abstract: The SARS-CoV-2 virus causing COVID-19 disease has emerged expeditiously in the world and has been declared pandemic since March 2020, by World Health Organization (WHO). The destructive effects of SARS-CoV-2 infection are increased among the patients with pre-existing chronic conditions and, in particular, this review focuses on patients with underlying cardiovascular complications. The expression pattern and potential functions of SARS-CoV-2 binding receptors and the attributes of SARS-CoV-2 virus tropism in a physio-pathological state of heart and blood vessel are precisely described. Of note, the atheroprotective role of ACE2 receptors is reviewed. A detailed description of the possible detrimental role of SARS-CoV-2 infection in terms of vascular leakage, including endothelial glycocalyx dysfunction and bradykinin 1 receptor stimulation is concisely stated. Furthermore, the potential molecular mechanisms underlying SARS-CoV-2 induced clot formation in association with host defense components, including activation of FXIIa, complements and platelets, endothelial dysfunction, immune cell responses with cytokine-mediated action are well elaborated. Moreover, a brief clinical update on patient with COVID-19 disease with underlying cardiovascular complications and those who had new onset of cardiovascular complications postCOVID-19 disease was also discussed. Taken together, this review provides an overview of the mechanistic aspects of SARS-CoV-2 induced devastating effects, in vital organs such as the heart and vessels.

Keywords: SARS-CoV-2; COVID-19; heart; blood vessels; thrombosis; glycocalyx; bradykinin; cardiovascular disease

\section{Introduction}

Rapidly evolving coronavirus (COVID-19) disease that has drenched millions of lives on our planet is caused by a novel strain of severe acute respiratory syndrome (SARS) coronavirus, which was first reported in Wuhan city of Hubei Province in China, in late 2019 [1]. The World Health Organization (WHO) has declared thoughtful alertness of the global pandemic during a novel coronavirus outbreak on 11 March 2020 [2]. The de novo sequences of 2019-novel (n) CoV genome obtained from lung lavages of infected patients has revealed a distinct clade that are clustered together within the sarbecovirus subgenus with a novel lineage $\beta$ (beta) coronavirus organization and is reported similar to two types of bat-derived SARS such as coronavirus, ZC45 and ZXC21 [3], exhibiting a rapid contagiousness with an accelerated human-to-human transmission [4]. Despite several 
viral antigenic components, the spike (S) proteins present on the surface of the SARS-CoV-2 are majorly responsible for corona associated pathogenesis, by firmly attaching to the receptors on the host cell membrane $[5,6]$. Until today, angiotensin converting enzymes-2 (ACE2) and transmembrane protease, serine 2 (TMPRSS2) serve as two major SARS-CoV-2 functional host cellular entry receptors [7]. In addition to TMPRSS2, cathepsin L (CTSL), furin contributes in assisting the cleavage of $S$ protein with facilitating the virus cellular entry $[8,9]$. Very recently, the expression of tyrosine-protein kinase receptor UFO (AXL) receptor on host pulmonary and bronchial epithelial cells has been shown to promote SARSCoV-2 infection [10]. The S protein of SARS-CoV-2 binds to the human ACE2 receptor with a dissociation constant (KD) of $14.7 \mathrm{nM}$ in comparison to the $\mathrm{S}$ protein of SARS-CoV, which is $325.8 \mathrm{nM}$ [11], indicating a higher sensitivity of SARS-CoV-2 (S) protein binding affinity to ACE2 than SARS-CoV. The availability and heterogeneous expression of these cognate receptors that bind to the SARS-CoV-2 virus provoke infectivity and transmissibility of the virion to afflict multiple organs $[12,13]$. Furthermore, the expression of these receptors varies between individuals and between different organs [13]. The COVID-19 disease manifests from self-limiting, mild to extremely severe with accelerated mortality, where underlying comorbid conditions remain to be the decisive factor in disease progression and outcome $[14,15]$. This review majorly focuses on the involvement of SARS-CoV-2/receptor axis in the pathophysiological outcome of vital organs, heart and blood vessels. This includes SARS-CoV-2 receptor expression pattern and function, SARS-CoV-2 tropism and cellular residence and a potential SARS-CoV-2 induced genesis of vasculopathy associating leakage and thrombosis. This review also provides a cumulative overview of evidence based clinical data obtained from patients with COVID-19 disease, who (i) harbored preexisting cardiovascular diseases and (ii) developed cardiac-related complications, during the pandemic.

\section{SARS-CoV-2 and Its Receptors in Cardiac Pathophysiology}

\subsection{SARS-CoV-2 Receptor Expression and Virion Tropism and Outcome in Heart Tissues}

In terms of anatomy and physiology, the heart is one of the complex and key organs with four distinct functional cardiac chambers and has been decoded for heterogenous cell population content that includes ventricular cardiomyocytes, atrial cardiomyocytes, cardiac fibroblasts, endothelial cells (ECs), pericytes, smooth muscle cells (SMCs), neuronal cells (NCs), adipocytes, mesothelial cells, lymphoid and myeloid cells [16], where cardiomyocytes are the most abundant cell type. While the pattern of cellular expression of SARS-CoV-2 receptors, ACE-2 and TMPRSS2, were found to be differential and higher in the adult human heart than fetal heart, minimal expressions were noticed in the adult coronary arteries [17]. Interestingly, the adult heart exhibited the highest percentage of ACE-2 positive SMCs $(10.38 \%)$ that is followed by the expression of ACE-2 in cardiac fibroblast (5.38\%), cardiomyocytes (4.98\%), ECs (2.96\%) and macrophages (MФ) $(1.97 \%)$ [17]. Other studies have evidently reported the highest expression of ACE2 on cardiac pericytes that are crucial for myocardial microcirculation and since they are located on the exterior surface of capillaries or venules, unlike the SMCs that are aligned inside the arteries [18], pericytes are more susceptible to SARS-CoV-2 attack in the human heart [19]. However, the fetal heart exhibited the highest percentage of ACE-2 positive mast cells, followed by red blood cells (RBCs), cardiomyocytes, T and B cells, $M \Phi$, cardiac fibroblast and ECs [17]. The cardiomyocytes associated with ACE2 receptors are majorly localized at the plasma membrane [20]. Furthermore, the expression of another vital SARS-CoV-2 receptor, TMPRSS2, that primarily cleaves the (S) proteins of SARS-CoV-2 virus in aiding the fusion with host cell membrane was also evident in adult endothelial cells followed by cardiomyocytes and to certain extent in SMCs and M $\Phi$. These TMPRSS2 are predominantly found in the nucleus and cytoplasm of both normal and diseased hearts with cardiomyopathy [20]. Though minimal expression of TMPRSS2 was found in the heart in comparison to the lung tissues, underlining a lesser extent, of heart ECs, cardiomyocytes and SMCs to SARS-CoV-2 infections [21], it is undoubtedly difficult to affirm the degree of vulnerability since other 
two SARS-Cov-2 (S) protein priming proteases (CSTL and FURIN), which compensates for lowered heart TMPRSS2 expressions, were evidently reported in the adult heart [17].

While high-throughput RNA sequencing and proteomic profiling has revealed an elevated heart tissue expression of ACE2 receptor, interestingly, a conventional based western blot method on myocardial biopsies has revealed an elevated expression of an additional SARS-CoV-2 receptor, $\mathrm{AXL}$, in patients with heart failure [22], which reinforces the mechanism for effortless SARS-CoV-2 invasion and aggressiveness in pre-existing conditions. During myocardial infarction, the infarct associated MHC II $^{\text {high }}$ cardiac macrophages exhibited increased AXL expression. While cardiac macrophage with AXL sufficiency retained inflammatory phenotype that was assisted with copious amount of pro-inflammatory cytokine productions, such as interleukin (IL)- $1 \beta$, IL-6 and tumor necrosis factor-alpha (TNF- $\alpha$ ), the AXL deficient cardiac macrophages were polarized into reparative MHClow phenotype that was biased into anti-inflammatory cytokines productions, such as IL-10 and transforming growth factor- $\beta$ eta (TGF- $\beta$ ). Moreover, lipopolysaccharide (LPS)-stimulated AXL positive M $\Phi$ induced the NLRP3 inflammasome, which was evaluated by cleaved caspase 1 (p10) with concomitant production of IL-1 $\beta$, while the impaired activation of AXL negative $M \Phi$ was noticed with decreased tumor necrosis factor-alpha (TNF- $\alpha$ ) production with circumstantial increase in IL-10, indicating the role of AXL in TLR-4 augmentation and inflammasome activation. Of note, AXL sufficient $M \Phi$ promoted enhanced glycolysis to compensate for the energy demands needed for sustaining the pro-inflammatory state in response to infection induced inflammatory stimuli. This glycolytic reprogramming that occurs inside cardiac $M \Phi$ is dependent on hypoxia inducible factor- 1 alpha $($ HIF-1 $\alpha$ ) [23]. Both HIF- $1 \alpha$ signaling and IL-1 $\beta$ production are independently achieved through the phosphorylation of STAT-1 activation that is promoted by AXL [23]. It was noted that AXL expression was correlated with the SARS-CoV-2 virus titer in COVID-19 patients, indicating upregulated AXL expression during the infection [10] and indeed virus replication are further amplified in glucose-rich micro-environment, where virus-induced metabolic alterations occur at the mitochondrial level with reactive oxygen species (ROS) production. These SARS-CoV-2 induced maladaptation favors the stabilization of HIF- $1 \alpha$ to support their replication efficiency and to sustain the hyper-inflammatory status through the IL-1 $\beta$ production [24]. Of note, the SARS-CoV-2 virus is known to induce STAT-1 dysregulation [25]. These evidence-based reports could, in part, support the SARS-CoV-2 associated cardiac pathogenicity with AXL receptor manipulation. Moreover, in heart sections, the tropism of the SARS-CoV-2 virus was confirmed within the cardiomyocytes in the left atrium [20], where both actively transcribed virus RNA and viral proteins found inside cardiomyocytes induced cellular alterations, including increased cardiomyocyte volumes with intracellular edema, together with disarranged, and plurifocally clumped myofibrils. However, the sarcolemma and the mitochondria of cardiomyocytes remained undamaged, which does not indicate cardiomyocyte death [26]. In contrast to this, another report has found SARS-CoV-2 induced foci of cardiomyocyte necrosis and the virus has shown tropism towards endocardium endothelial cells, cardiac associated macrophages, neutrophils, and fibroblasts [27].

The tropism exhibited by the SARS-CoV-2 virus towards cardiac tissues due to several aforementioned SARS-CoV-2 receptors on the cardiac system, especially on cardiomyocytes and pericytes, could culminate in cardiac injuries, where the virus directly invades into the myocardial cells by binding to the ACE2 receptor to cause myocardial injuries. In addition to this, the bystander effect plays a significant role in mediating cardiac injuries, which include (a) systemic hyper responsiveness due to cytokine storm; (b) cardiac tissue hypoxia due to respiratory failure; (c) coronary plaque destabilization, (d) induction of coronary thrombosis, which are elicited by high SARS-CoV-2 load, are also responsible for cardiac muscle dysfunction and injuries, causing acute or fulminant myocarditis [28,29]. Though direct cardiac injury mediated by SARS-CoV-2 virus is not completely understood, it was evident that this virus does replicate inside cardiomyocytes and are localized at the perinuclear region of the cytoplasm, causing viral-mediated cytopathic effects, including 
apoptosis which was reflected by the cleaved caspase-3 expression and cessation of beating in $72 \mathrm{~h}$ post-infection, as demonstrated by beat rate contractility analysis [30]. These data were further supported at the transcriptional level, where RNA sequencing was performed to demonstrate the upregulation of signature genes involved in apoptosis and oxidative stress [31]. The underlying molecular mechanism reports that the double stranded RNA (dsRNA), the viral replication intermediates, of the SARS-CoV-2 virus are being sensed by the cytosolic protein kinase R (PKR) of cardiomyocytes, where PKR undergoes autophosphorylation prior to the phosphorylation of eukaryotic initiation factor 2 (elF2 $\alpha$ ), leading to cell apoptosis due to arrest in further translation [32]. The next major intracellular event that occurs during the course of SARS-CoV-2 infection is the oxidative stress, which dictates an increased ratio of pro-oxidants to antioxidants in a living system and is considered to be pivotal in determining the cell fate. Here, the SARS-CoV2 viral RNA are presumed to be sensed by TLR-7 further activates NADPH oxidase 2 (NOX2) to produce reactive oxygen species (ROS). During viral infections, e.g., SARS-CoV2 infection, the NOX associated ROS production induces inflammation and tissue damage. Therefore, NOX2 activation were described to be one of the underlying mechanisms for myocardial injury, as evaluated by the increased cardiac troponin (cTn1) [33,34]. In general, a counter balance mechanism is being induced via nuclear factor E2-related factor 2 (Nrf2) pathway as antioxidant responses to circumvent the excessive ROS levels. Here, Nrf2 which is associated in the cytoplasm with kelch-like ECH-associated protein 1 (Keap1) is inclined to proteasomal degradation, especially when the ROS level is minimal. However, Nrf2 dissociates from cytoplasmic Keap1 to translocate into the nucleus and bind to the promoters of genes encoding for antioxidant enzymes such as superoxide dismutases and glutathione peroxidases [33]. Nevertheless, the ROS induced cell injuries tend to inhibit the Nrf2 pathway, as evidenced by the suppression of Nrf2 related antioxidant gene expression during SARS-CoV-2 infection [35,36]. Taken together, these multiple events mediated by SARS-CoV-2/ ACE2 axis intensify cardiac injuries in COVID-19 disease.

\subsection{Atheroprotective Role of ACE2 Receptor, Its Variants and Association with SARS-CoV-2 Susceptibility to Cardiac Risk}

One of the SARS-CoV-2 receptors, ACE2, a homolog for ACE, is a key negative regulator of the renin-angiotensin system (RAS) [37] that plays a significant role in protecting the cardiac functions, especially in curtailing prothrombotic events [38]. There exists a dynamic equilibrium between ACE and ACE2 under the steady-state condition, where the ACE2 acts as a counter regulator of ACE by converting angiotensin II to vasodilatory molecules, Ang 1-7, which is $>300$ times effective than converting angiotensin I to Ang $1-9$. These vasodilatory ang 1-7 molecules [39] aid in protecting the endothelial cell functions by (i) decreasing the protein levels of adhesion molecules, vascular cell adhesion molecules (VCAM) and E-selectin; and (ii) decreasing the production of chemokine and cytokine, monocyte chemoattractant protein-1 (MCP-1) and IL-6 [40] (iii) limiting monocyte recruitment; (iv) attenuating NADPHox induced reactive oxygen species (ROS) generation, partly mediated through the decreased expression of p22phox, a vital component of superoxide-generating vascular NADH/NADPH oxidase [41,42]; (v) increasing eNOS and NO production (eNOS/NO) pathways with a concomitant decrease in NADPH oxidase 2 and oxidase 4 (Nox2 and 4) (Nox/ROS) pathways [43]. The antithrombotic and anti-inflammatory effects exerted by Ang 1-7 is mediated by binding to the Mas receptor $[44,45]$ and by eliciting the production of $\mathrm{NO}$ and prostacyclin, an anticoagulant. Of note, Mas knockout has shown shorter bleeding time and increased thrombi size [46]. In addition, when SARS-CoV-2 binds to ACE2 causing insufficient ACE2 expression, the counterbalanced expression of Ang II activates NOX to generate ROS which leads to tissue injury [36]. Overall, the ACE2 receptor deficit has been shown to develop atherosclerosis in $\mathrm{LDL}^{-/-}$mice [47], dictating that these aforementioned and validated observations affirm the atheroprotective role of the ACE2 receptor, which is mediated through the ACE2/Ang $1-7 /$ Mas axis [46]. 
Despite atheroprotective attributes of ACE2, the underlying pathophysiological conditions such as diabetes, chronic obstructive pulmonary diseases (COPD), malignancies [48] and cofounding factors including cigarette smoking [49], and age [50] tend to upregulate ACE2 receptors which adds further complexity to becoming highly detrimental when binding to the SARS-CoV-2 virus. However, an enzymatic cleavage of ectodomain ACE2 receptor occurs by the action of a disintegrin and metalloproteinase 17 (ADAM-17) also known as tumor necrosis factor-a converting enzyme (TACE), generating active and soluble (s) forms of ACE2 [51,52]. Since angiotensin II is elevated during the heart failure condition, the activity of ADAM-17 is internally promoted by angiotensin II that is reported in several cardiac diseases, as a feedback system to sustain the ratio of angiotensin II/ACE2 expression [39]. The cleaved and shed sACE2 circulates in the plasma of patients with heart failure [53], aortic stenosis [54,55] and coronary artery disease (CAD) [56] and positively correlates with worsening disease prognosis. Of note, plasma sACE2 has been accounted as a highly ranked and independent determinant for cardiovascular mortality compared to other established cardiovascular risk factors [57]. Nevertheless, it has been demonstrated that the human recombinant sACE2 tends to decrease angiotensin II and concomitantly increases Ang 1-7 [58-60]. Furthermore, the generated soluble variant of ACE2 serves as a decoy receptor and binds to the spike proteins of SARS-CoV-2 virion in order to limit the virus uptake by membrane-bound ACE2 receptors [61]. These issues further interrogate whether the circulating native SACE2 could exert a protection against angiotensin II mediated cardiac dysfunction or could it effectively bind to SARS-CoV-2 spike protein as the patients with comorbid conditions, including heart failure or CAD are more vulnerable to the SARS-CoV-2 mediated severity, despite elevated SACE2 levels in their circulation. This links to the further query on whether these native sACE2 is functionally impaired due to the amino acid changes (polymorphisms) or variants, generating weak intermolecular interaction with virus spike protein [62]. Indeed, these variants contribute to different affinities of ACE2 with the spike protein receptor-binding domain (RBD) region, promoting disparity in the rates of infectivity. This could explain the reason behind the incapability of fencing SARS-CoV-2 virus, by a high concentration of plasma circulating naïve sACE2 in patients with underlying heart failure.

\section{SARS-CoV-2, and Its Receptors in Blood Vessel Pathophysiology}

\subsection{Endothelium-Expressed Receptors and Vascular Leakage during SARS-CoV-2 Infection}

Next to the expression pattern on cellular fractions of the human heart, ACE2 receptors were shown to be expressed in vessel associated endothelial cells from small and large arteries and veins in all the tissues [12]. Compared with adult and fetal heart, coronary arteries exhibited the lowest expression of ACE-2 receptors, including fibroblasts, SMCs, ECs and in pericytes of intramyocardial microvessels [17]. The TMPRSS2 protein was readily found in the endothelium of coronary arteries and in pericytes of intramyocardial microvessel [20]. Of note, human endothelial cells also upregulate an AXL receptor during viral infection [63]. However, the SARS-CoV-2 receptor expression varies among microvascular and macrovascular beds between different organs [64]. These endothelial expression of SARS-CoV-2 associated receptors increase the vulnerability of the inner layer of the vessel to virus attack and, indeed, the SARS-CoV-2 infected patient has been reported with severe microvascular blood vessel leakage $[65,66]$, which acts as an exit window for SARS-CoV-2 viruses to invade other organs. Such microvascular leakage could be mechanistically linked to the (i) endothelial glycocalyx dysfunction [67] and (ii) bradykinin receptors (B1R) trigger via kallikrein-kinin system (KKS) activation [68], during the interaction between SARS-CoV-2 and its receptor(s). The schematic illustration of molecular mechanisms behind vascular leakage that possibly occurs during COVID disease is shown in Figure 1A,B. 
A

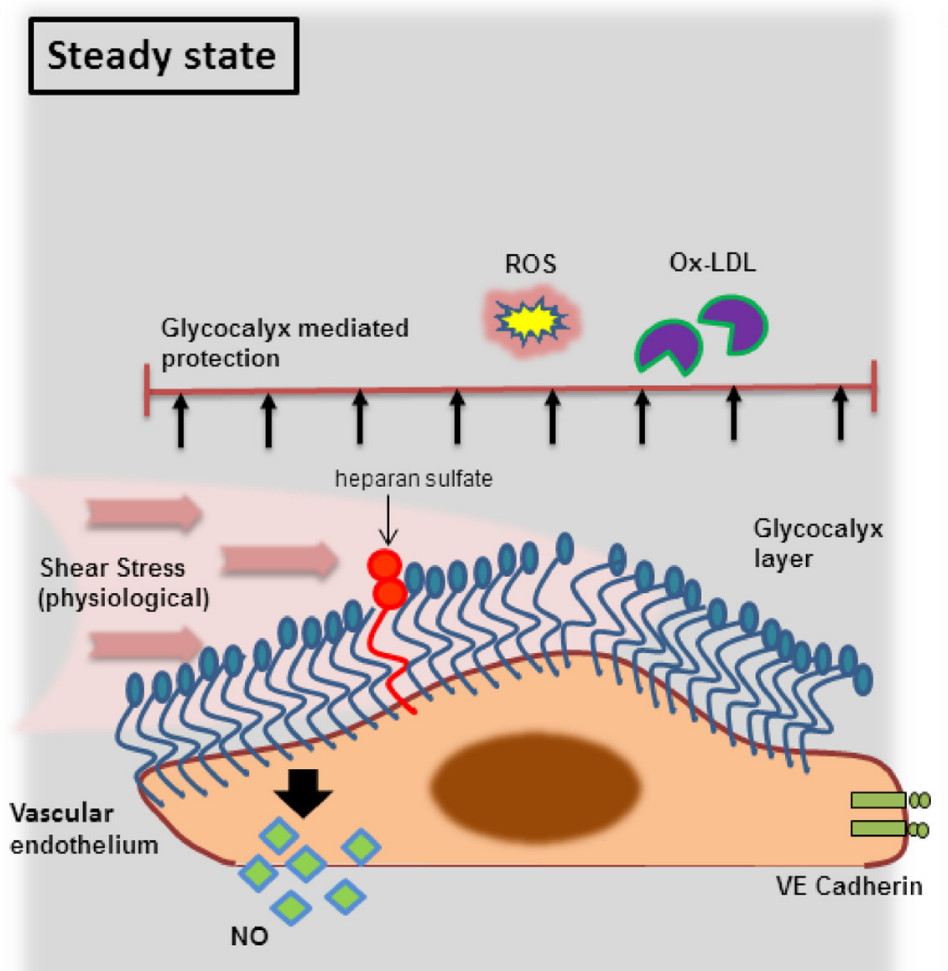

\section{COVID-19 disease}

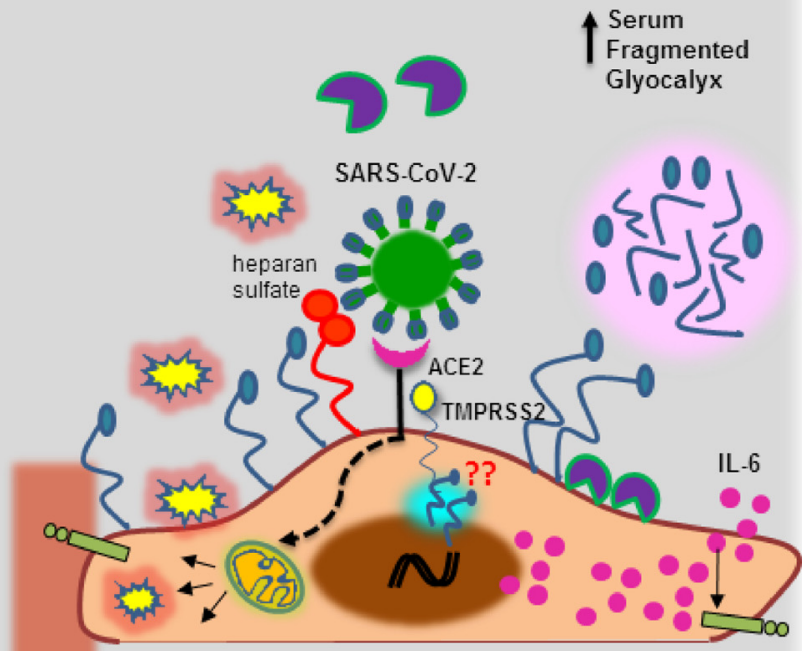

Microvascular leakage

B

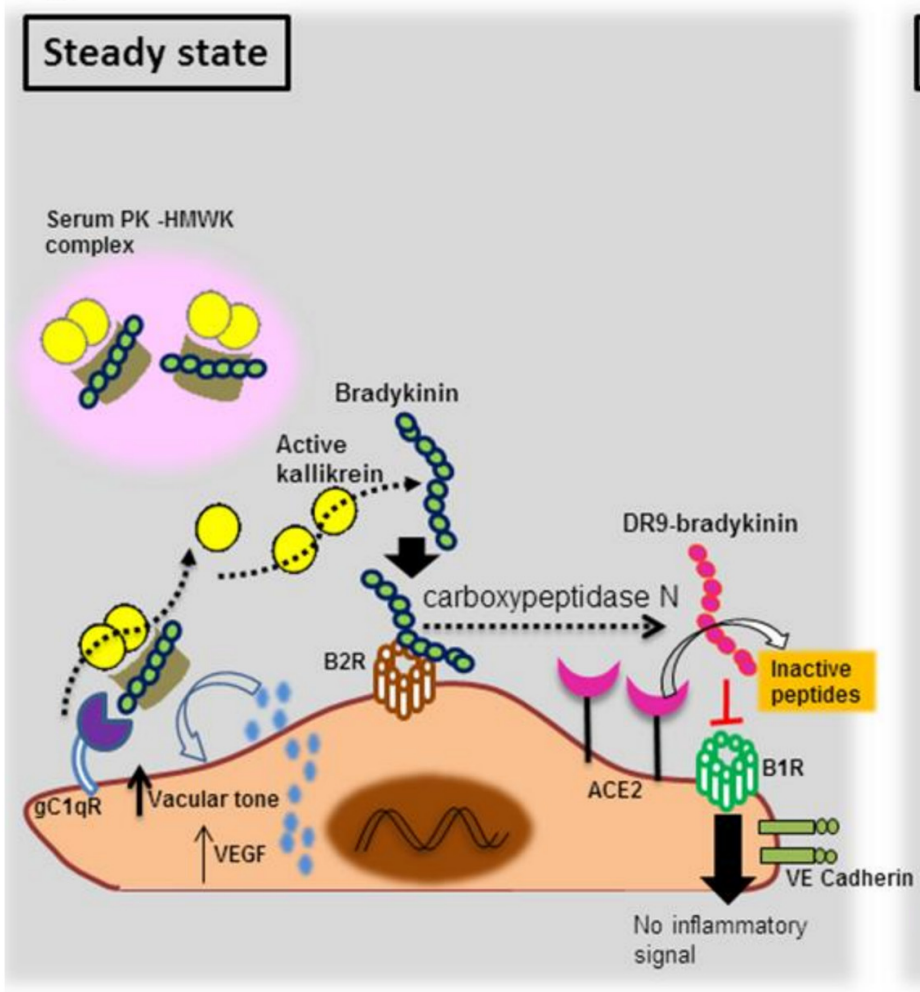

\section{COVID-19 disease}

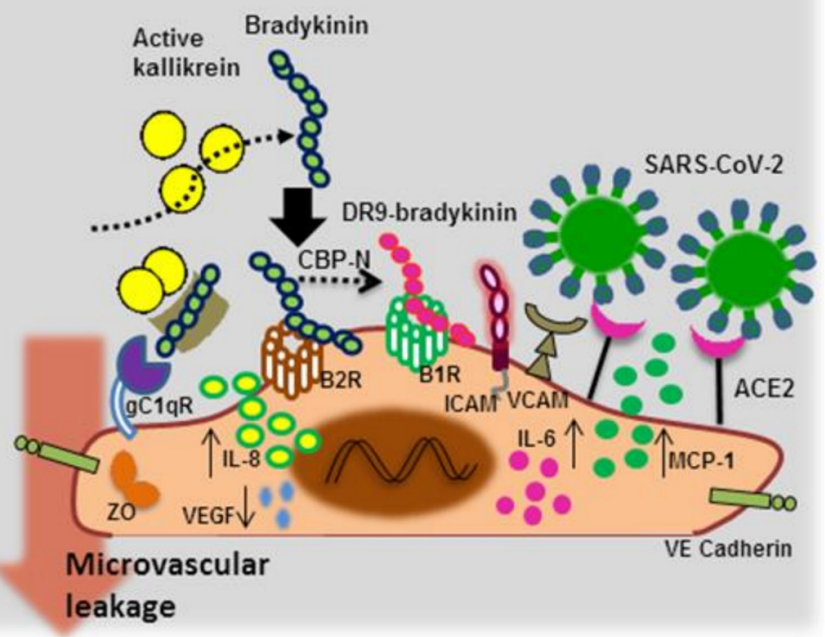

Figure 1. Potential molecular mechanisms underlying vascular leakage during SARS-CoV-2 infection. (A) Under the steadystate condition, vascular endothelium expresses qualitative and quantitative glycocalyx, which protects the endothelial damage with plasma-circulating ox-LDL and free oxygen radicals termed reactive oxygen species (ROS). In addition, these 
vascular endothelial cells tend to secrete nitric oxide (NO), which supports vasodilation and improved circulation, under physiological shear stress condition. In patients with the COVID-19 disease, there might be a heavy loss of the endothelial glycocalyx with possible impairment of glycocalyx re-synthesis. This is more evident when COVID-19 patients exhibited high levels of the fragmented glycocalyx. When a SARS-CoV-2 virus binds to angiotensin-converting enzyme 2 (ACE2) receptor expressed on endothelial cells, they might tend to induce mitochondrial ROS production, which decreases the junctional proteins, such as vascular endothelial (VE)-cadherin expression, and increases the production of IL-6 proinflammatory cytokines. Due to the loss of the glycocalyx layer, plasma-circulating ROS and ox-LDL can easily damage the endothelial cell membrane, causing endothelial dysfunction. Of note, the SARS-CoV-2 virus utilizes a component of the glycocalyx layer, one of the glycosaminoglycan side chains called heparan sulfate, as a cofactor to assist spike protein-mediated viral invasion. These SARS-CoV-2-induced changes in endothelial cells might lead to vascular leakage. For S protein priming the transmembrane protease, serine subtype 2 (TMPRSS2) is used. (B) Under the steady-state condition, the serum-circulating pre-kallikrein (PK) that are complexed with high molecular weight kininogen (HMWK) bind to endothelial-expressed receptors $\mathrm{gClqR}$, where PK activates into kallikrein that liberates bradykinin, an inflammatory component, from HMWK. These generated bradykinins are also processed to generate DR9-bradykinin by carboxypeptidase $\mathrm{N}(\mathrm{CBP}-\mathrm{N})$. The bradykinin and the metabolite DR9-bradykinin bind to the bradykinin receptors B2R and B1R, respectively. However, ACE2 receptors bind to DR9-bradykinin and convert it into an inactive peptide to prevent inflammation. In patients with the COVID-19 disease, the SARS-CoV-2 virus hijacks ACE2 and is thereby competing with DR9-bradykinins. These ACE2 unbound DR9-bradykinins remain free to bind to B1R to induce a devastating inflammatory signal in the endothelial cells by (i) upregulating IL-6, MCP-1 and IL-8; (ii) upregulating intracellular adhesion molecule (ICAM) and vascular cell adhesion molecule (VCAM); (iii) downregulating vascular endothelial growth factor (VEGF), which is required for vascular tone; (iii) decreasing VE-Cadherin required for junctional integrity. Moreover, tight junctional proteins, such as zonula occludens ( $\mathrm{ZO})$, are also reduced. These endothelial dysfunctions might lead to microvascular leakage during COVID-19 disease.

\subsubsection{Endothelial Glycocalyx Dysfunction during SARS-CoV-2 Infection}

Vascular endothelial glycocalyces are the membrane-bound macromolecules that are attached to the endothelial cell membrane and are composed of core proteins, which consist of membrane-anchored proteoglycans (syndecan, glypican), long-chain hyaluronic acid (HA) and glycosaminoglycan side chains (heparan sulfate, chondroitin sulfate) [69]. These glycocalyces serve as "sentinels" against inflammation by preserving endothelial cell functions associated with (i) the vascular permeability barrier; (ii) blood flow homogeneity; (iii) the protection of ECs from oxidants, pro-inflammatory cytokines and inflammatory immune cells [70]. Further, mechanotransduction of shear stress stabilizes glycocalyx, which is crucial for physiological nitric oxide (NO) synthesis from endothelial (e) NOS [70]. An impaired endothelial glycocalyx is reported among patients with underlying comorbidities, including diabetes, obesity, chronic kidney disease, cardiovascular disease [71] as well as in people with advancing age [70] and smoking habits [71]. Intriguingly, SARS-CoV-2 patients exhibited elevated levels of fragmented vascular endothelial glycocalyces [72]. It has been proposed that shedding of glycocalyx occurs due to an evolutionary mechanism that can be newly synthesized from the golgi apparatus of the same cells for regulating endothelial homeostasis [73]. This is obviously evident when the SARS-CoV-2 virus uses one of the glycosaminoglycan side chains, heparan sulfate, as an assisting cofactor for the spike protein mediated viral entry [74], in addition to ACE2, expressed on endothelial cells [12]. While it is uncertain to expect re-synthesis of glycocalyx when it is being utilized by SARS$\mathrm{CoV}-2$ virus infection under pre-existing chronic conditions, the patchy glycocalyx layer are easily targeted by ROS and cytokines, especially IL-6, which are induced by a SARS-CoV-2 virus $[75,76]$. These secreted molecules further reduce the endothelial junctional proteins, VE Cadherin and zonula occludens-1 (ZO-1) [76], causing increased vascular permeability which mainly occurs due to functional loss of endothelial glycocalyx [77] (Figure 1A).

\subsubsection{Endothelial Bradykinin 1 Receptor (B1R) Trigger during SARS-CoV-2 Infection}

An inflamed vascular microenvironment created during SARS-CoV-2 infection could also lead to the activation of the kallikrein-kinin cascade [78], which exists in two different 
forms i.e., plasma KKS and tissue KKS [79]. The plasma KKS, including factor XII (FXII), prekallikrein (PK) and high molecular weight kininogen (HMWK), has been strongly associated with vascular inflammation [80] and also reported to activate the intrinsic pathway of blood clotting [81]. Plasma PK circulates in an inactive form and is complexed with HMWK. These PK complexed HMWK binds to its three known endothelial cell binding receptors: urokinase plasminogen activator receptor (uPAR), globular C1q receptor (gC1qR,) and cytokeratin 1 (CK1) [82]. Endothelial bound PK results in the production of its active form, kallikrein [83]. Plasma serine protease kallikrein further catalyzes the liberation of bradykinin, a potent inflammatory substance, from an HMWK [84]. The produced bradykinin either directly exerts inflammatory or vasoactive action by binding to endothelial expressed bradykinin receptor 2 (B2R) or processed by carboxypeptidase $\mathrm{N}$ to generate DR9-bradykinin (des-Arg-9-bradykinin) that activates bradykinin receptor 1 (B1R) to deliver inflammatory signals [85]. Both RAS and KKS systems are well appreciated for their indispensable attributes in vascular biology by counter-regulating each other [86], where ACE2 is involved in the degradation of DR9-bradykinin into inactive peptides, while ACE inactivates bradykinin [87] to culminate KKS cascades [85]. When the invaded SARSCoV-2 virus binds directly to ACE2 receptor, there is an uninterrupted interaction between DR9-bradykinin, and endothelial expressed B1R receptor that promotes the endothelial expressions of (i) pro-inflammatory cytokines and chemokine, such as IL-6 and IL-8 and MCP-1 respectively, and (ii) adhesion molecules, such as ICAM-1 and VCAM, contributing to leukocyte adherence on endothelial cells and (iii) VE-cadherin destabilization [88]. Concurrently, B1R stimulation decreases the (i) expression of vascular endothelial growth factor (VEGF) that is needed to maintain the vasculature and (ii) junctional protein occluden, which is crucial for the tight endothelial junction formation [89]. These effects culminate in vascular hyperpermeability and hence the attributes of non-degraded bradykinins causing vascular hyperpermeability promote blood vessel leakage and angioedema, during SARSCoV-2 infection, [88], leading to amplified inflammation and SARS-CoV-2 dissemination (Figure 1B).

\subsection{Endothelial Elemental Changes and Clot Formation during SARS-CoV-2 Infection}

One of the major attributes of the SARS-CoV-2 virus is the induction of clot formation within a blood vessel, which draws a special interest to all clinicians and researchers. The incidence of vessel-associated thromboembolism in COVID-19 patients treated in intensive care units (ICU) ranges between $20-50 \%$ [90-92], but is lowered to $12 \%$ (in approximate) by treating with the anticoagulant substances, such as heparin [93]. Despite anticoagulation therapy, a significant proportion of SARS-CoV-2 infected patients still suffer from pulmonary embolism [94]. It is evident that point-of-care thermoelectrometry analyses of blood from COVID-19 patients have shown a rapid clot formation that was linked to increased fibrin polymerization due to the infectious disease $[95,96]$. Thus, patients with SARS-CoV-2 infection suffer from a severe coagulopathy, which is thought to be one of the main drivers of the pulmonary and extra pulmonary dysfunctions [97]. This coagulopathy is barely linked to routine clinically detectable diagnostic coagulation markers, where the key parameters are elevated D-dimers and fibrin or fibrinogen degradation products $[95,96,98-100]$. While this accounts for disseminated intravascular coagulopathy (DIC) that is commonly noticed among the patients with severe sepsis or acute respiratory distress syndrome, the SARS-CoV-2 induced coagulopathy is thought to be slightly different from DIC, because the prothrombin time (PT), activated partial thromboplastin time (aPTT), fibrinogen levels and platelets count are much less affected [101]. Recently, a three-stage concept of the SARS-CoV-2 induced coagulopathy was proposed: (1) D-Dimer elevation; (2) D-Dimer elevation + PT and aPTT prolongation along with thrombocytopenia; (3) critical illness and laboratory presentation that is more comparable to DIC [102]. Though the underlying molecular mechanisms are still obscure, intensive investigations are being conducted linking coagulopathy to COVID-19 disease, where the cornerstones of the clotting dysregulation during SARS-CoV-2 infection are found to be majorly due to the 
following crosstalk with the host components, (a) pro-coagulant factors (FXIIa); (b) platelet dysregulation; (c) complement activation; (d) endothelial dysfunction; (e) cellular immune responses; (f) cytokine storm. A scheme illustrating the possible molecular mechanisms and cellular components involved in coagulopathy during the course of COVID-19 disease is shown in Figure 2.

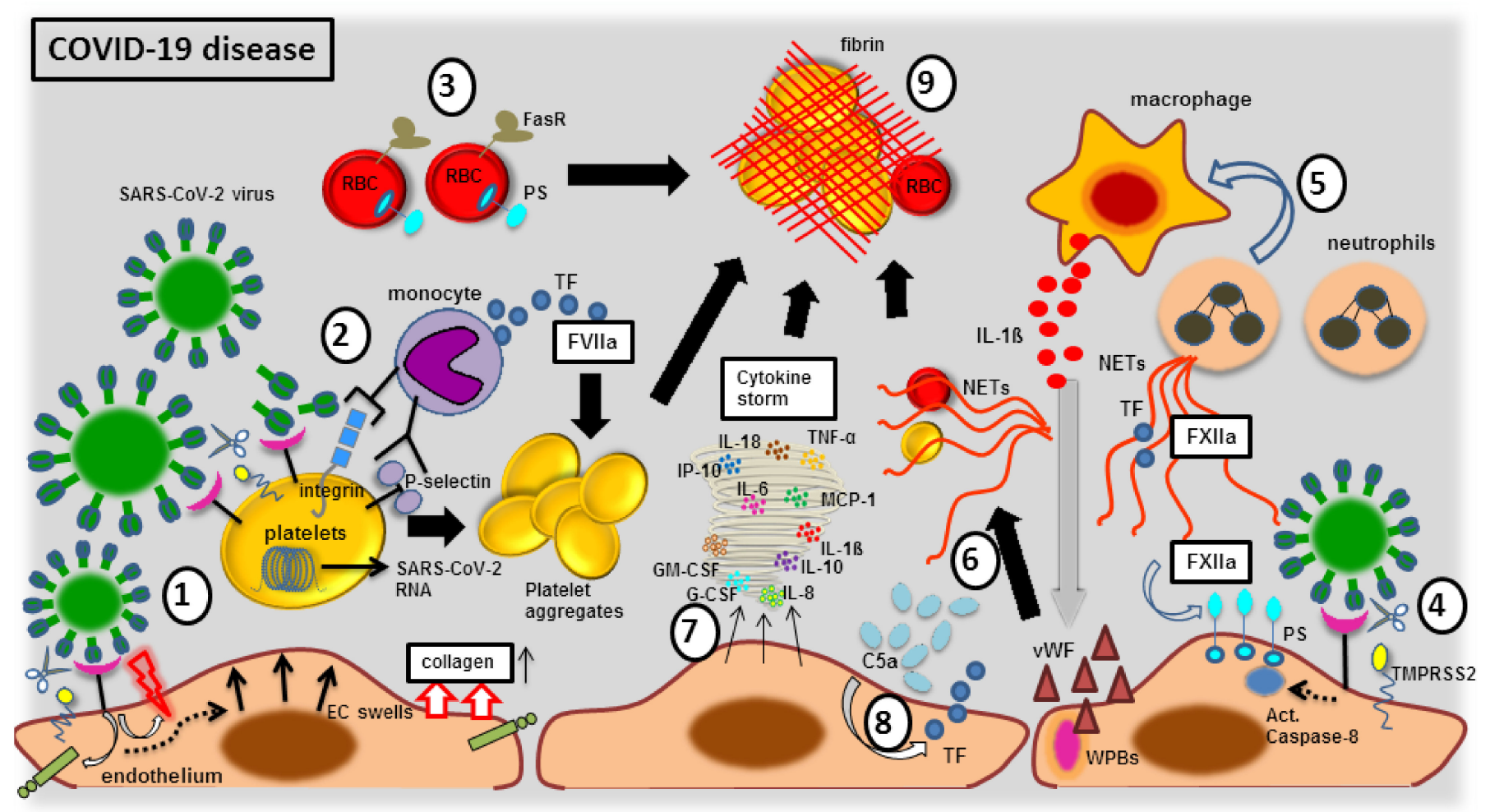

Figure 2. Potential molecular mechanisms involved in coagulopathy during SARS-CoV-2 infection. (1) When SARS-CoV-2 binds to ACE2 receptors expressed by endothelial cells (ECs), they damage the endothelial cell membrane, which leads to intracellular changes such as endothelium swelling, collagen exposure, and decreased junctional proteins. The collagen causes platelet aggregation and clot formation. (2) Since platelet expresses ACE2, SARS-CoV-2 binds to platelets and activates, as evidenced by the expression of activation and adhesion molecules, P-selectin and integrin, respectively. These adhesion molecules bind to circulating monocytes, which secretes tissue factor (TF) that is known to activate the extrinsic coagulation pathway and leads to clot formation. (3) The red blood cells (RBCs) that are recruited to the inflamed vasculature undergo changes in their symmetry and thereby expressed phosphatidylserine (PS), which might lead to thrombin formation. (4) SARS-CoV-2 induces caspase 8 in the endothelial cells, which expose PS on the cell surface. This attracts the FXIIa coagulation component to initiate clot formation. (5) The recruited neutrophil at the site of inflammation releases neutrophil extracellular traps (NETs) that contain TF and FXIIa. These NETs induce vessel resident macrophages to release IL-1 $\beta$ pro-inflammatory cytokine that acts on vascular endothelium to liberate von Willebrand factor (vWF). Weibel-Palade bodies (WPBs) are elongated secretory organelles specific to endothelial cells that contain von Willebrand factor (vWF) and a variety of other factors. (6) These vWFs further induce NETs that serve as the docking site for platelets and RBCs. (7) These changes in the vascular microenvironment induce a massive amount of cytokine cocktail called "cytokine storm," which ultimately induces a coagulation pathway to form a clot. (8) Further, complement C5b act on endothelium to induce TF, which leads to clot formation. (9) Cumulatively, the molecular and cellular mechanisms that are coordinately responsible for inducing and reinforcing the fibrin clot in COVID-19 positive patients.

\subsubsection{The Blood Vessel Clot Formation with FXIIa Factor}

In comparison to data gathered from several viral infection models [103], it has been predicted that an auto-activation of coagulation factor XIIa (FXIIa) occurs in contact with the SARS-CoV-2 virus [104]. The FXIIa is one of the main proteins of the contact system (CS), which is an innate inflammatory defense mechanism orchestrated against any negatively charged foreign or misfolded proteins, or nucleic acids such as DNA or RNA or 
microorganisms such as viruses, found in the intravascular niche $[105,106]$. This speculates that either the whole coronaviruses, which contains conserved negatively charged amino acids located within domain III in the carboxyl end of nucleocapsid proteins [107] or the SARS-CoV-2 RNA that are circulating in the bloodstream [108] are readily capable of inducing FXII-associated intrinsic coagulation pathway to form a pathological thrombus [104]. In fact, a pulmonary vessel wall isolated from COVID-19 positive lung tissues exhibited increased expression and activity of FXIIa [109], showing the commencement of the pathogenic pro-coagulant chain. This FXIIa was activated by an accumulated neutrophil extracellular traps (NETs) indicating an impaired clearance of NETs [109]. Further, the coagulation cascade activation is evidenced by increased plasma levels of thrombinantithrombin-complexes (TAT) and fibrin among COVID-19 patients [110,111], suggesting an activation by FXIIa [112].

\subsubsection{The Blood Vessel Clot Formation with Platelet Activation}

In addition to FXIIa, activated platelets exert an intrinsic coagulation pathway that is strongly evidenced during SARS-CoV-2 infection, as COVID-19 patients exhibit thrombocytopenia that is associated with critically severe condition [102,113]. Almost one trillion of platelets circulate in the blood vessel to maintain the vasculature integrity and forms a hemostatic plug during trauma to cease the bleeding [114]. Upon activation, these platelets tend to aggregate to promote clotting and generation of fibrin thrombi and are therefore majorly involved in thrombosis $[115,116]$. The SARS-CoV-2 virus has the potential to activate platelets, as they bind directly to ACE2 to enter into human platelets and are further primed by TMPRSS2 which is also expressed on platelets [117]. These upregulated ACE2 and TMPRSS2 were confirmed at both RNA and protein levels and were reported to be more comparable with the quantity that was found on human PBMCs [117]. Upon SARS-CoV-2 binding, the ACE2 levels on platelets are readily decreased due to internalization and subsequent degradation [117]. The concentration of SARS-CoV-2 virus with $1 \times 10^{5} \mathrm{PFU}$ can induce platelet aggregation within $30 \mathrm{~min}$ in the presence of agonists, such as thrombin, collagen or ADP, as evidenced by (i) increased dense granule secretion (ATP release); (ii) integrin $\alpha_{\mathrm{IIb}} / \beta_{3}$ activation; (iii) P-selectin (CD62P) expression; (iv) enhanced platelet spreading; (v) accelerated clot retraction [117]. Of note, not only the whole SARSCoV-2 virus, but also its spike proteins were capable of eliciting platelet activation [117]. These SARS-CoV-2 spike proteins were also shown to enhance (i) platelet aggregation, (ii) P-selectin expression, and (iii) alpha-granule release, by ACE2 phosphorylation leading to downstream signaling with the mitogen-activated protein kinase (MAPK) pathway, including phosphorylation of ERK, P-38 and JNK, and thereby leading to platelet hyperactivity and subsequent release of coagulation proteins, such as factor V and XIII [117]. The SARS-CoV-2 RNA was also detected inside platelets from older COVID-19 patients, irrespective of the disease severity. These disease-sensitized platelets increased the phosphorylation status of $\mathrm{PKC} \delta$, which is key regulator platelets activation, granule secretion, and aggregation [118]. Further, activated platelets in patients with COVID-19 have larger platelet volume (MPV), indicating that it is adhered to the endothelial wall to increase in its radius [119]. These large-sized platelets exhibit increased coagulatory potential as they are able to bind more fibrinogen on their surface with a greater level of protein phosphorylation [120,121]. In fact, these subpopulations of large-sized platelets expose phosphatidylserine (PS) to enhance a coating over the platelets by binding to coagulation factors and plasma proteins and providing a pro-coagulant surface and phenotype during the SARS-CoV-2 infection [122]. These platelets also produce extracellular microvesicles containing phosphatidylserine to promote further coagulation [118]. Furthermore, the proinflammatory cytokines IL- $1 \beta$ and IL- 6 produced by macrophages and monocytes at inflamed blood vessels [123], have been shown to increase the interaction between platelets and monocytes. Such interactions amplified monocytic expression of tissue factors (TF) to orchestrate extrinsic coagulation pathway, as evidenced by the markers of the hypercoagulatory state, D-Dimers and fibrinogen, among COVID-19 patients [124]. 
Furthermore, the P-selectin was aberrantly expressed on platelets upon SARS-CoV-2 infection [125-127], where the elevated P-selectin is linked to enhanced platelet-leukocyte and platelet-endothelial interactions and activation. Thus, adjoining of platelets with other cells types (leukocytes and endothelial cells) are pro-coagulatory and therefore could be reasoned behind the hypercoagulatory state in COVID-19 disease [128].

\subsubsection{The Blood Vessel Clot Formation with Complement System Activation}

Complement components are the representatives of innate immunity that enhances the attributes of antibodies binding to the invaded pathogens to facilitate their elimination [129]. Complements are mainly generated by the hepatocytes of the liver, however, other cell types such as endothelial cells are also capable of producing the complement components $[130,131]$. Though complement and coagulation are two distinct systems, there exists an interconnection between the proteins of both the cascades, as evidenced with (i) the activation of complement complex $\mathrm{C} 1$ leading to the initiation of the classical complement pathway, by coagulation factor XIIa [132]; (ii) MASP-2 (MBL-associated serine protease 2) is a component of the lectin complement pathway, which significantly contributes to the activation of thrombin and to the formation of fibrin mesh [133]; (iii) the expression of TF on endothelial cells by both the C5a component and MAC (membrane attack complex), when the blood vessels are compromised during SARS-CoV-2 infection [134]. The endothelial TF activity induced by the C5a complement factor further leads to the development of disseminated intravascular coagulation (DIC), as commonly observed among critically ill COVID-19 patients. Of note, plasma levels of C5a complement components were increased among patients with the COVID-19 disease [135]. It is reported that MASP-1 and 2 expression were also increased among these patients, where the N protein of SARS-CoV-2 interacts with MASP-2, causing complement over-activation. The accumulated MASP-2 cleaves prothrombin to thrombin, whereas increased MASP-1 activates endothelial cells through the protease activated receptor PAR-4 to secrete pro-inflammatory cytokines to enhance the chemotaxis of monocytes and neutrophils to the damaged blood vessels. Further, MASP-1 involves in cleaving fibrinogen to fibrin to form a clot [136].

\subsubsection{The Blood Vessel Clot Formation with Endothelial Dysfunction}

The vascular endothelium is one of the most important players in regulating the coagulatory state to maintain vascular tone and homeostasis, which became evident when endothelial damage led to thrombosis in patient with sepsis [137-139]. Likewise, extensive research is being focused on EC dysfunction following SARS-CoV-2 infection. It has been demonstrated that neuropillin-1 positive endothelial cells of small and medium-sized vessels were infected with SARS-CoV-2 [140]. Case reports have shown direct invasion of the SARS-CoV-2 virus into ECs, leading to EC activation and apoptosis as well as pyroptosis $[97,141]$. Thus, the accumulation of viral elements in the ECs and inflammatory cells cause endotheliitis. Though COVID-19 disease could primarily be regarded as a pneumonia, it could be precisely defined as endotheliitis in multiple organs [142]. Such an inflamed endothelial cell synthesizes and secretes copious amounts of von Willebrand factor (vWF) multimers, which is an acute phase reactant, such as C-reactive protein (CRP) [143]. The vWF are stored in the Weibel-Palade bodies (WPBs) of endothelial cells as a highly prothrombotic protein. Despite heterogeneous function, the vWF multimers are well known for their capability to support platelet aggregation and to safeguard FVIII from proteolytic degradation in blood flow to amplify hemostasis and thromobic events. Of note, patients with COVID-19 disease exhibited elevated levels of vWF [144]. During exocytosis, these vWF are released as very high-molecular-weight (HMW) proteins that exhibit an extraordinarily long platelet catching string such as structure [145]. These HMW vWFs are generally regulated in size by ADAMTS13, a vWF-cleaving protease [146]. However, a significant alteration in the platelet-vWF-ADAMTS13 axis was found among COVID-19 patients, including high vWF levels with high platelet counts and an increase of 3-7 fold of vWF antigen to ADAMTS13 activity ratio that was strongly associated with 
COVID-19 severity [147]. These data firmly support a sustained ECs activation during SARS-CoV-2 infection [144]. In fact, a comparative analysis from autopsy lungs taken from both COVID-19 and influenza infected patients have shown (i) unique vascular features with severe endothelial injury; (ii) EC infected SARS-CoV-2 virus with disrupted cell membrane; (iii) increased ACE2 positive ECs; (iv) EC swelling, disrupted intercellular junctions and loss of contact with the basal membrane, which were noticed among COVID19 patients. Of note, COVID-19 damaged pulmonary vessels from a COVID-19 patient have shown disseminated thrombosis with microangiopathy [97]. Thus, endothelial dysfunction remains to be a prime factor for any microvascular damage by switching the vascular equilibrium to vasoconstriction that is assisted with ischemia, inflammation and a procoagulant state [148]. Next, the flow of blood, either laminar or turbulent, determines the intensity of shear stress on these underlying vessels associated endothelial cells [149], where laminar shear stress induces NO that makes the vessel wall inflammoresistance. However, turbulent shear stress has been noticed during SARS-CoV-2 infection-causing pathological deformation of vascular wall architecture by inducing vasoconstrictors, platelet aggregation and coagulation factors [150]. Since endothelial glycocalyx maintains the integrity of the vascular structure by regulating shear stress, SARS-COV-2-associated hijacking of the glycocalyx element as its receptor disrupts the endothelial structure and thereby imbalances the shear stress that might be one of the causes for the activation of coagulation factors [151].

\subsubsection{The Blood Vessel Clot Formation with Cellular Immune Response}

Cellular pathways, including blood circulating and tissue-resident leukocytes, especially monocytes and macrophages, are considered to be the main drivers for the SARSCoV-2 induced coagulopathy [152]. In COVID-19 patients, an interaction between the platelet and monocyte, which is mediated by P-selectin and integrin $\alpha_{\mathrm{IIb}} / \beta_{3}$ expression, has strongly induced the monocytes to express the tissue factor (TF) [124], which is in line with increased TF plasma levels in these patients $[153,154]$. The secreted TF are well known to induce an extrinsic coagulation cascade [155]. These peripheral blood monocytes arrive to the inflammatory sites and infiltrate the tissue to differentiate into macrophages, which were found on SARS-CoV-2 infected lung tissues [141,156]. Due to the expression of ACE2 receptors, SARS-CoV-2 can easily interact with macrophages, followed by macrophage activation and intensified inflammatory response [157]. Despite antiviral attributes, these viral containing macrophages surprisingly serve to relocate by egressing from the lung tissues to the other organs [158]. The macrophage contained SARS-CoV-2 RNA could trigger TLR7, the RNA sensors, through the adaptor MyD88 and RIG-I through the adaptor MAVS, both of which induce type 1 IFNs production that is activated via the transcription factors STAT1, STAT2 and IRF9, leading to upregulation of caspase-11 and other IFN-inducible proteins [159]. Concomitant activation of caspase-1 and inflammasome pathway leads to macrophage pyroptosis by cleaving gasdermin that forms pores on the plasma membrane to facilitate IL-1 $\beta$ release [160]. Upon inflammasome activation, the pyroptotic macrophage releases TF that further initiates coagulation cascades [160]. The secreted TF evidently plays key role in initiating disseminated intravascular coagulation (DIC), a pathological state of systemic coagulation [161] that was evidently noted among SARS-CoV-2 infected patients [162]. Of note, targeted cell apoptosis remains to be the hallmark during SARS-CoV-2 infection and was shown to have a direct relationship with severity in COVID-19 patients [163]. Human macrophages, T lymphocytes and lung endothelial cells were shown to undergo apoptosis via caspase 8 activation by the SARS virus, where the externalizing phosphatidylserine (PS) from apoptotic cells are shown to possess pro-coagulant properties. Here, the factor XII binds to the apoptotic cells via PS and has shown to be vital for apoptosis-induced thrombin generation [164]. Since macrophages are considered to be the main source of proinflammatory cytokines IL- $1 \beta$, IL-6, IL- 8 , IFN- $\gamma$ and TNF- $\alpha$, these macrophage-secreted cytokines act on pulmonary vessel ECs, leading to their activation [165]. This has also been shown on COVID-19 lung autopsies, where alveolar macrophages expressing IL- 6 and MCP-1 found in the lung tissues, leading to 
endothelial damage and necrosis that were evidenced by IL-6 secreting macrophages and ECs adhering to vascular thrombi [166]. Apart, neutrophils were also reported to drive the coagulatory cascade activation in COVID-19 patients. Infiltrating neutrophils in the lung tissue of COVID-19 patients have released neutrophil extracellular traps (NETs) upon activation [167]. Elevated NET values were shown in the blood of COVID-19 patients [168], and the released NETs further induce macrophages to release IL- $1 \beta$, where cooperated action of NETs and IL-1 $\beta$ lead to excessive damage on pulmonary endothelium [169]. This injured endothelium tends to release vWF, which further activates neutrophils as well as blood platelets. As a positive circuit loop, these activated platelets induce inflamed neutrophils to secrete excessive NETs, which serve as a basal structure upon which erythrocytes, fibrins and blood platelets, tend to aggregate and support clot development [169]. In fact, the sera obtained from COVID-19 patients are the strong source for NETs production from control neutrophils [170]. The formed NETs from COVID-19 patients have been shown to carry active TF, which induces the extrinsic coagulation system, and these thrombogenic NETs might also directly induce TF expression on human aortic endothelial cells to enhance pro-coagulant attributes [153]. Additionally, NETs trigger PAI-1 (plasminogen activator inhibitor-1) release from ECs [171,172]. PAI-1 is pro-coagulatory, as it functions to inhibit the tissue plasminogen activator (tPA) and urokinase (uPA), both of which are responsible for fibrinolysis of blood clots [173]. Next, red blood cells (RBCs) that comprise $35-45 \%$ of the blood volume are directly involved in thrombin generation and platelet activation [174], by expressing the death receptor FasR and loses its membrane asymmetry to expose negatively charged phosphatidylserine (PS) on its cell surface [175]. This subpopulation of PS-positive ( $\mathrm{PS}^{+}$) RBCs generates thrombin [174]. Additionally, an increased $\mathrm{PS}^{+} \mathrm{RBCs}$ positively correlates with biomarkers of coagulation activation [176]. Further, when the RBCs are added to platelet-rich plasma, increased thrombin is being produced [177]. It was shown that RBCs exhibited the greatest deposition of platelet aggregates on a collagen surface under low $\left(150 \mathrm{~s}^{-1}\right)$ shear stress rates compared with high $\left(1700 \mathrm{~s}^{-1}\right)$ in veins [175] and it is evident that SARS-CoV-2 imbalances the shear stress [178]. These attested functions of blood cellular fractions might render the hypercoagulatory state among SARS-CoV-2 infected individuals.

\subsubsection{The Blood Vessel Clot Formation with Cytokine Storm}

A dysregulated host immune response to the SARS-CoV-2 virus leads to systemic release of cytokines from inflamed cells, termed as "cytokine storm," which is evident in severely affected COVID-19 patients [179] and also has been linked to clot formation [180]. The cytokine storm is characterized by high serum levels of various cytokine mixtures, such as IL-1 $\beta$, IL-6, IL-7, IL-8, IL-9, IL-10, IL-18, IL-33, FGF (fibroblast growth factor), G-CSF (granulocyte-colony stimulating Factor), GM-CSF (granulocyte-macrophage colony-stimulating factor), IFN- $\gamma$ (interferon- $\gamma$ ), CCL-2 (CC-chemokine ligand 2), IP-10 (interferon-gamma induced protein 10), MCP-1, MIP-1 $\beta$ (Macrophage Inflammatory Protein $1 \beta$ ), PDGF (platelet-derived growth factor), TNF- $\alpha$, and VEGF [181,182]. These mixed cytokine stews are pro-coagulatory in nature and induce multiple pathways associated with fibrin generations, including platelet activation and aggregation, activation of coagulation factors and complement components, renin-angiotensin system and tissue-resident macrophages $[183,184]$. In particular, proinflammatory cytokines, IL-1B, IL-6, IL-8 and TNF- $\alpha$, resulted in platelet hyperactivation with increased clumps, suggesting that these molecules possess profound effect on rumpled fibrin clot with trapped RBCs [185,186]. The IL-6 cytokine was correlated with the symptomology of COVID-19 patients, including pulmonary inflammation and excessive lung damage [187]. Interestingly, the suppressor of cytokine signaling 3 (SOCS3) was decreased in these patients [188], indicating that the negative regulator of IL-6 cytokine secretion is being hampered. In particular, SOCS3 inhibits STAT- 3 activation by using gp130 receptor, a part of the receptor complex for IL-6 cytokine family [189-191] and the reduced phosphorylation of STAT-3 decreases IL-6 synthesis. The upregulation of SOCS3 is coordinated in the presence of platelet factor 4 (PF4), 
a chemokine found in abundance inside the platelet $\alpha$-granules, to attenuate the STAT$3 /$ IL-17A pathway [192] and further these PF4 are involved in the inhibition activation of the thrombin activatable fibrinolysis inhibitor (TAFI) [193], which protects the formed clot from lysis. Of note, mice with dysfunctional endothelial SOCS3 and activated STAT-3 exhibit pro-thrombotic phenotype, as evidenced by the increased expression of the gene encoding Factor III, urokinase receptor and urokinase that further support the formation of DIC [194]. Apart, chemokines such as IP-10 and MCP-1 were increased among critically ill COVD-19 patients, which were positively correlated with the fibrin degradation products (FDP) and D-dimers [195]. Further, when SARS-CoV-2 infects monocytes probably at the endothelium-monocytes interface, it activates the inflammasome pathway via NLRP3 components and induces pyroptosis to activate caspase 1 , which cleaves gasdermin to form pores at the monocyte surface to expel copious amounts of IL-1B, leading to a hyperinflammatory state [196]. In fact, these key cytokines, including TNF- $\alpha$, increase the local concentration of thrombin via heterogenous TFs, where thrombin acts on macrophages and platelets, recruited to the endothelial injured site, and cleaves p33 IL-1 $\alpha$ which is activated and released by the action of thrombin [197]. These thrombi cleaved IL- $1 \alpha$ were found to be elevated among COVID-19 patients, exhibiting severe lung injury [198]. Next, TNF- $\alpha$ plays a key role in impairing an anticoagulant function, by diminishing thrombomodulin activity in the endothelial cells [199]. One such well-known anticoagulant pathway is the protein C-protein S-thrombomodulin pathway, where thrombin-thrombomodulin complex on the endothelial cell surface activates protein $C$ that augments by binding to the endothelial cell protein $C$ receptor (EPCR) and thereby protein $C$ plays a vital role in inactivating the coagulation factors Va and VIIIa, assisted by a cofactor protein S [200]. The cytokine TNF- $\alpha$ downregulates EPCR on the endothelial cells [201], which ceases the further activation of protein $C$, thereby imbalancing coagulation-anticoagulation system. Taken together, these cytokine storms mediated damage to vascular endothelium activates pro-coagulatory cascade, by expressing TF and VWF molecules and exposing the collagen to blood that breaches the endothelial barrier and enhances platelet binding to ECs to induce platelet activation and aggregation. Concomitantly, a diminished generation of components of anticoagulation and fibrinolysis further boost lung microthrombosis. Such an imbalanced coagulation system generated by copious amounts of cytokines forms DIC and triggers a decompensated thrombocytopenia via excessive aggregation and passive exhaustion of platelets among SARS-CoV-2 infected patients [202]. The list of proinflammatory cytokines with steady state function and association with SARS-CoV-2 related hypercoagulopathy is summarized in Table 1.

Table 1. Cytokine directory in relation to SARS-CoV-2 associated hypercoagulopathy.

\begin{tabular}{|c|c|c|c|}
\hline Cytokine Name and Type & Primary Functions & $\begin{array}{l}\text { Potential Role in SARS-CoV-2 } \\
\text { Associated Hypercoagulopathy }\end{array}$ & References \\
\hline IL-6, proinflammatory & $\begin{array}{l}\text { Induces CRP } \\
\text { Antibody production } \\
\text { Effector T cell } \\
\text { development }\end{array}$ & 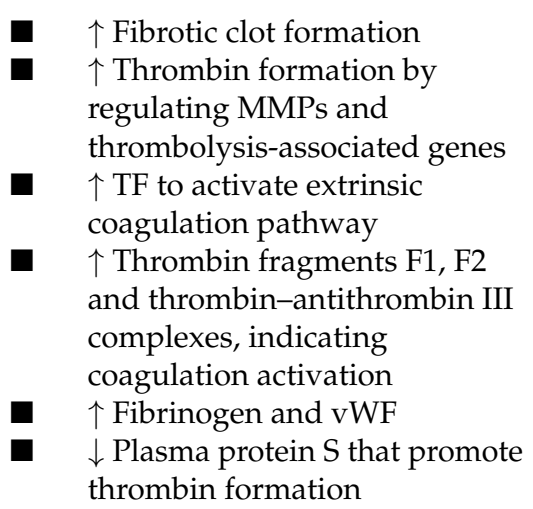 & [203-205] \\
\hline
\end{tabular}


Table 1. Cont.

\begin{tabular}{|c|c|c|c|}
\hline Cytokine Name and Type & Primary Functions & $\begin{array}{l}\text { Potential Role in SARS-CoV-2 } \\
\text { Associated Hypercoagulopathy }\end{array}$ & References \\
\hline IL-1 $\alpha$, proinflammatory & $\begin{array}{l}\text { - Promote high grade } \\
\text { inflammation } \\
\text { - Act as "alarmin" }\end{array}$ & $\begin{array}{l}\text { - } \uparrow \text { Monocyte-endothelium } \\
\text { interaction that } \uparrow \mathrm{TF} \text { activity }\end{array}$ & [206] \\
\hline IL-1ß, proinflammatory & $\begin{array}{l}\text { Inflammasome } \\
\text { activation } \\
\text { Macrophage pyroptosis }\end{array}$ & 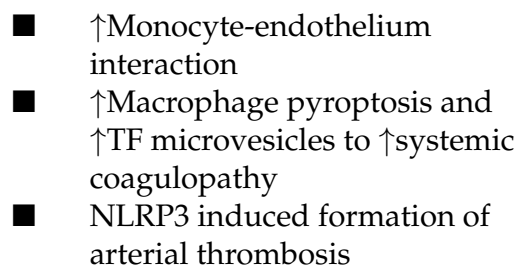 & {$[160,207]$} \\
\hline IFN- $\gamma$, proinflammatory & $\begin{array}{l}\text { Play role in antiviral } \\
\text { adaptive immune } \\
\text { responses } \\
\text { Activator of } \\
\text { macrophages }\end{array}$ & 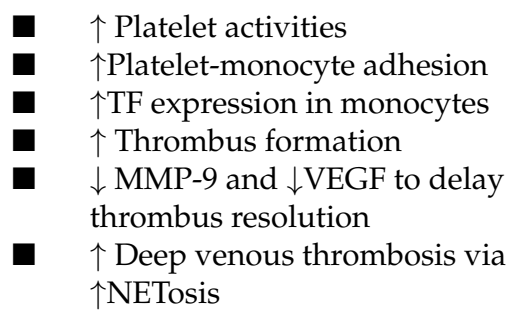 & {$[205,208,209]$} \\
\hline IL-2, growth factor & $\begin{array}{l}\text { - Promote T cell activation } \\
\text { - Promote tolerance by } \\
\text { expanding regulatory T } \\
\text { cells (Tregs) } \\
\text { Immune suppressive } \\
\text { activities of Tregs }\end{array}$ & $\begin{array}{l}\text { - } \uparrow \text { Endothelial activation of } \\
\text { PAI-1 } \\
\downarrow \text { 口 Fibrinolysis } \\
\text { घ Impair anti-coagulant function } \\
\text { of vascular endothelium }\end{array}$ & {$[205,210]$} \\
\hline $\begin{array}{c}\text { IL-12, } \\
\text { differentiation factor }\end{array}$ & $\begin{array}{l}\text { Differentiation of naive } \\
\text { to effector cells } \\
\text { Amplify cytotoxic } \\
\text { activities of NK cells and } \\
\text { CD8+T cells } \\
\text { Role in early } \\
\text { inflammation }\end{array}$ & $\begin{array}{l}\uparrow R B C \text { adhesion with each other } \\
\text { and } \uparrow \text { Agglutination causing } \\
\text { aberrant hemorheology } \\
\text { affecting blood flow } \\
\text { Platelet activation and } \\
\text { spreading with } \\
\uparrow \text { hypercoagulation }\end{array}$ & [211] \\
\hline IL-18, proinflammatory & $\begin{array}{l}\text { - Promote high grade } \\
\text { inflammation } \\
\text { Facilitates } \mathrm{TH}_{1} \\
\text { responses } \\
\text { Inflammasome } \\
\text { activation }\end{array}$ & 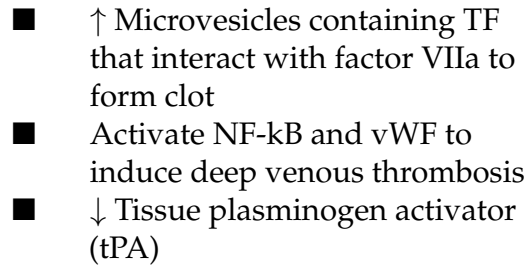 & {$[212,213]$} \\
\hline $\mathrm{TNF} \alpha$, proinflammatory & $\begin{array}{l}\text { - Promote high grade } \\
\text { inflammation } \\
\text { Facilitate tissue } \\
\text { pathology }\end{array}$ & $\begin{array}{l}\text { - Induction of TF on endothelial } \\
\text { cells } \\
\downarrow \text { - Thrombomodulin activity for } \\
\text { anticoagulant function } \\
\downarrow \text { EPCR expression on } \\
\text { endothelial cells and } \downarrow \text { Protein } \\
C \text { activation needed for } \\
\text { anticoagulation } \\
\uparrow \text { Release of PAI-1 }\end{array}$ & {$[201,214-216]$} \\
\hline $\begin{array}{l}\text { GM-CSF, hematopoiesis } \\
\text { cytokine, growth factor }\end{array}$ & $\begin{array}{l}\text { Induces stem cells to } \\
\text { generate subpopulation } \\
\text { of granulocytes and } \\
\text { monocytes } \\
\text { Involved in } \\
\text { myelopoiesis }\end{array}$ & $\begin{array}{l}\text { - } \uparrow \text { Monocytic production of TF } \\
\text { Activation of coagulation } \\
\text { system }\end{array}$ & {$[217,218]$} \\
\hline
\end{tabular}


Table 1. Cont.

\begin{tabular}{|c|c|c|c|c|}
\hline Cytokine Name and Type & & Primary Functions & $\begin{array}{l}\text { Potential Role in SARS-CoV-2 } \\
\text { Associated Hypercoagulopathy }\end{array}$ & References \\
\hline MCP-1, proinflammatory & $\boldsymbol{\square}$ & $\begin{array}{l}\text { Chemoattractant factor } \\
\text { for } \\
\text { monocyte-macrophages } \\
\text { system }\end{array}$ & 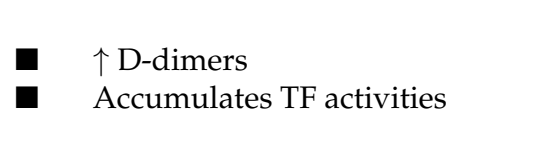 & [219] \\
\hline IL-10, anti-inflammatory & - & $\begin{array}{l}\text { Regulation of the } \\
\text { immune responses } \\
\text { Expansion of Tregs }\end{array}$ & $\begin{array}{l}\text { - No direct evidence for } \\
\text { thrombus formation } \\
\text { - Few reports support on } \\
\text { cytokine activation by } \\
\text { recombinant (r) IL-10 }\end{array}$ & [220-222] \\
\hline IL-17A, proinflammatory & - & $\begin{array}{l}\text { Role in allergic } \\
\text { responses } \\
\text { Induce inflammation } \\
\text { against extracellular } \\
\text { pathogens }\end{array}$ & $\begin{array}{l}\text { - Recombinant (r) IL-17A } \\
\text { promotes deep vein thrombosis } \\
\text { - } 1 \text { platelet activation and } \\
\text { aggregation; neutrophil } \\
\text { infiltration and endothelium } \\
\text { activation }\end{array}$ & [223] \\
\hline
\end{tabular}

Where, IL-interleukin; CRP—C-reactive protein; MMPs—matrix metalloproteinase; TF—tissue factor; NLRP—NLR family pyrin domain containing 3; IFN— $\gamma$-interferon gamma; VEGF—vascular endothelial growth factor; NETosis—Neutrophil extracellular traps; PAI—1plasminogen activator inhibitor-1; $\mathrm{RBC}$-red blood cells; NK—natural killer; vWF-von Willebrand factor; $\mathrm{TH}_{1}-\mathrm{T}$ helper 1 ; $\mathrm{NF}-\mathrm{kB}$ nuclear factor kappa-light-chain-enhancer of activated B cells; TNF $\alpha$-tumor necrosis factor alpha; EPCR —endothelial protein C receptor; GM-CSF-granulocyte monocyte colony-stimulating factor; MCP-1-monocyte chemoattractant protein-1.

\section{Comprehensive Clinical Observations on SARS-CoV-2 Infected Patients Associating with Cardiovascular Complications}

\subsection{The Impact of COVID-19 on Patients with Cardiovascular Diseases}

The severity of COVID-19 disease is associated with an increased risk, especially, in patients with pre-existing cardiovascular disease. Early reports have indicated that cardiovascular complications are a common comorbid condition observed among SARS-CoV-2 infected patients [224]. When patients with mild or moderate disease were compared with patients with critical illness, cardiovascular diseases, specifically hypertension, diabetes, coronary artery disease and heart failure, were associated with worse prognosis $[99,224]$. This prompted the health authorities to declare all persons with a history of cardiovascular disease as being at high risk for COVID-19, both in terms of susceptibility and worse disease outcomes. Nevertheless, the data remain controversial regarding susceptibility to SARS-CoV-2 infection. In a meta-analysis of seven early studies from China with 1576 infected patients, the prevalence of hypertension was $21.1 \%$, diabetes $9.7 \%$ and cardiovascular disease $8.4 \%$ were reported [225], while another systematic review analyzing data from six studies among 1527 COVID-19 patients in China showed that the proportion of patients with hypertension, cardio-cerebrovascular disease and diabetes mellitus was $17.1 \%, 16.4 \%$ and $9.7 \%$, respectively [226]. Although the prevalence of diabetes mellitus and arterial hypertension in the COVID-19 cohort was comparable to that in the Chinese population as a whole, the prevalence of cardio-cerebrovascular disease was significantly higher. However, other data do not support the notion of increased susceptibility of patients with hypertension and/or diabetes to COVID-19. For instance, one study showed that coronary heart disease, hypertension and diabetes mellitus were associated with an increased risk of death in a univariate comparison, but not in a multivariate analysis [227]. These discrepancies in availing clinical data pinpoint that CAD, hypertension and diabetes mellitus, alone do not appear to aggravate the likelihood for an increased susceptibility to COVID-19. Instead several other existing basic and clinical parameters may play some key role in disease progression, which includes age, gender, magnitude of inflammation and pro-thrombotic state, that are the best predictors of multiorgan failure, while pre-existing cardiovascular morbidities should be considered as modulating (risk) factors [228]. Further, the viral defense host cellular components are impaired in these patients with pre-existing 
cardiovascular disease [229] and with COVID-19 disease [230], where the antiviral effector immune cells, such as mucosal-associated invariant T cells (MAIT cells), were significantly reduced. These patients exhibit decreased levels of natural killer cells (NK cells) [231] and $\mathrm{CD}^{+} \mathrm{T}$ cells that are attested by the expressed exhaustion markers such as programmed death-1 (PD-1) and T-cell immunoglobulin and mucin-domain containing-3 (TIM-3) on its cell surface, implicating that the circulating so called antiviral immune cells remain defenseless and are correlated with the COVID-19 disease severity [232].

\subsection{The Impact of COVID-19 on Patients without Cardiovascular Diseases}

Though COVID-19 is primarily a pulmonary disease, it widely affects the cardiovascular system in multiple ways. Since the time when COVID-19 was declared to be a global pandemic by the WHO and in compliance with WHO recommendation of movement restrictions, many countries have strictly imposed a compulsory self-quarantine and restricted movements of their citizenries (lockdown/sit at home/home-office), including compulsion of wearing face masks and to maintain social distancing to prevent the SARSCoV-2 acquisition or transmission. On the other hand, social detachment or deprivation can significantly contribute to the physical inactivity. In particular, the restriction of physical activities has led to behavioral patterns that can lead to cardiovascular diseases (CVDs), which are the leading cause of the global mortality rate. The increase in this COVID restricted lifestyle [233] and/or substance misuse during the COVID-19 pandemic lockdown as a result of personal limitations in the COVID-19 lockdown is associated with the risk of death from chronic diseases such as cardiovascular diseases [234]. Given the fact that cardiovascular disease is the major comorbidity in COVID-19 patients and is closely related to the severity of COVID-19, during SARS-CoV-2 infection, the cardiovascular system is either directly (especially viral toxicity with sarcomere disassembly) and/or indirectly (e.g., cytokine storm) being affected by unknown pathomechanisms, leading to an increased incidence of cardiovascular associated changes in COVID-19 patients (Table 2) [235,236], where otherwise, these patients remained healthy prior to SARS-CoV-2 infection [27]. Though direct and indirect myocardial injury of COVID-19 and the impact on cardiovascular homeostasis remains elusive, regardless of morbidity, it is at least known, that cardiac injury is associated with higher mortality, due to (ii) admission to the intensive care unit (ICU), (ii) mechanical ventilation and (iii) coagulopathy in patients with COVID-19 [237]. A recent systematic review and meta-analysis could show that, the proportions of cardiac injury were $22 \%, 28 \%$ among hospitalized patients with COVID-19 or severe COVID-19 patients, respectively [238]. The incidences of cardiac injury in patients with COVID-19 $>60$ years $(30 \%)$ was about twofold than patients <60 years $(15 \%)$. Severe cases $(42 \%)$ have a sevenfold of prevalence cardiac injury than in their non-severe counterparts $(6 \%)$. Furthermore, cardiac injury is associated with an increased risk of all-cause mortality in patients with COVID-19 (OR 10.11, 95\% CI 4.49-22.77) and is vice versa, i.e., in patients with severe COVID-19, cardiac injury is associated with an increased risk of all-cause mortality (OR 16.79, 95\% CI: 5.52-51.02) [238]. Recent experimental results have shown that intervention in pathophysiology could prevent damage to the heart. Treatment with the commercially available bromodomain 2-selective bromodomain and extraterminal family (BET) inhibitor apabetalone has shown to reduce the (i) cytokine storm-induced diastolic dysfunction, (ii) ACE2 levels; and (iii) viral infection in cardiomyocytes [239]. 
Table 2. Potential direct and indirect mechanisms of SARS-CoV-2-mediated myocardial injury (modified according to Kurz et al. [228]).

\begin{tabular}{|c|c|c|c|c|}
\hline $\begin{array}{l}\text { ACE2-Mediated } \\
\text { Direct Damage }\end{array}$ & $\begin{array}{l}\text { Hemodynamic Strain } \\
\text { of Right Ventricle }\end{array}$ & $\begin{array}{l}\text { Hypoxia-Induced } \\
\text { Myocardial Injury }\end{array}$ & $\begin{array}{c}\text { Cardiac Vascular } \\
\text { Damage }\end{array}$ & $\begin{array}{c}\text { Systemic } \\
\text { Inflammatory } \\
\text { Response Syndrome }\end{array}$ \\
\hline $\begin{array}{l}\text { - Increased affinity } \\
\text { to ACE2 } \\
\text { Myocarditis-like } \\
\text { injury } \\
\text { RAAS } \\
\text { dysregulation }\end{array}$ & $\begin{array}{ll}\text { - } & \begin{array}{l}\text { Pressure/volume } \\
\text { increase in RV }\end{array} \\
\text { - } \\
\text { Increased RV wall } \\
\text { stress } \\
\text { - } \\
\text { RV dysfunction }\end{array}$ & $\begin{array}{l}\text { Energy depletion } \\
\text { - } \\
\text { Intracellular } \\
\text { acidosis } \\
\text { Mitochondrial } \\
\text { damage }\end{array}$ & $\begin{array}{l}\text { Endotheliitis } \\
\text { 口 Thrombus forma- } \\
\text { tion } \\
\text { 口 Lung embolism }\end{array}$ & $\begin{array}{l}\text { Cytokine storm } \\
\text { Dysregulated im- } \\
\text { munocyte } \\
\text { Uncontrolled in- } \\
\text { flammation }\end{array}$ \\
\hline
\end{tabular}

Where, ACE2- angiotensin converting enzyme 2; RAAS- renin angiotensin aldosterone system; RV-right ventricular.

COVID-19 has been associated with the development of several cardiac complications, including myocarditis, venous thromboembolic disease, acute coronary syndrome, acute myocardial infarction, arrhythmias, heart failure, cardiomyopathy, cardiogenic shock and cardiac arrest, including and coagulation abnormalities (Figure 3) [240,241]. These cardiac dysfunctional observations were also evident with two previous historical epidemics with coronavirus outbreaks, including SARS and MERS [242]. A Swedish study characterizes the causes of cardiac arrest before and within the COVID-19 pandemic [243]. During the pandemic phase, COVID-19 was involved in at least 10\% of all out-of-hospital cardiac arrests (OHCA) and $16 \%$ of in-of-hospital cardiac arrests (IHCA). Among COVID-19 cases, very alarmingly, 30-day mortality was increased 3.4-fold in OHCA and 2.3-fold in IHCA [243]. During COVID-19 pandemic, substantial numbers of children exhibited multiorgan inflammatory syndrome in children (MIS-C) or Kawasaki such as disease involving cardiogenic shock, signs of myocarditis, acute left-ventricular dysfunction as a potential risk for a lifethreatening condition [244,245]. Though pathophysiology of cardiovascular manifestations is multifactorial and not yet understood in detail in association with COVID-19 disease, several laboratory findings in COVID-19 patients show an increase in high-sensitivity cardiac troponin I (hs-cTnI), creatine kinase (CK)-myocardial band [31] and N-terminal probrain natriuretic peptide (NT-proBNP), which can be interpreted as an expression of myocardial involvement [246]. Whether late cardiac consequences are to be expected in COVID-19 patients was shown in the most recent work by Kotecha et al. [247]. One hundred and forty-eight severely ill COVID-19 patients with troponin elevation, a marker for cardiac damage, were examined by cardio-MRI at a median of 68 days after recovery. More than half $(54 \%)$ showed abnormalities in the heart. One was myocarditis-like injury $(26 \%)$ and the other was infarction and/or ischemia (22\%) and both pathologies (6\%). The results of the above-mentioned studies suggest that several mechanisms associated with SARS-CoV2 infection may affect the heart, including myocarditis and myocardial ischemia. Major possibilities would be that SARS-CoV-2 is probably triggering these clinical conditions either by eliciting systemic immune responses causing damage to the vital organs, where especially the SARS-CoV-2 virus possesses a high likelihood for inducing cross-reactivity with the host autoantigens as known by the concept called "molecular mimicry" [248] or by causing tissue damage through direct viral invasion and pathogenesis. Furthermore, it can also be postulated that COVID-associated myocarditis could be triggered, especially in individuals who are genetically predisposed to autoimmune diseases [249]. Moreover, vaccine associated adverse cardiovascular reactions are described in the literature, albeit rarely. Although the causality between vaccination and myocardial disease cannot be conclusively determined, there are cases of myocarditis associated with vaccine administration. Analyses of Vaccine Safety Surveillance System (VAERS) data in the USA from 1990 to 2018 in 620,195 individuals have shown that 708 (0.1\%) individuals meet the classic definition of myocarditis following vaccination. Similar to the aforementioned case, $72 \%$ of those affected described the onset of symptoms $\leq$ two weeks post vaccination [250]. Systemic events that were correlated to the presented case have been reported more frequently in 
younger vaccine recipients ( 16 to 55 years) in contrast to older vaccine recipients (over 55 years) and more frequently after the second dose. Studies have shown that adverse events after vaccination, namely with vaccines against smallpox (59\%), Hemophilus influenza type b $(22 \%)$ and hepatitis B $(18 \%)$, predominantly cause cardiovascular symptoms. Acute coronary syndromes, ventricular arrhythmias and cardiac arrest have been described [251]. In summary, the incidence of serious adverse events was rare and similar in the vaccine and placebo groups $(0.6 \%$ and $0.5 \%$, respectively). However, the triggering of cardiovascular complications among COVID-19 vaccine recipients is still obscure and is under intensified investigation. Given the fact that cardiovascular complications could be developed succeeding SARS-CoV-2 infection, the medical authorities must emphasize an urgent need to monitor the cardiology events in surviving COVID-19 patients as well as in COVID-19 vaccinated subjects for the surveillance of cardiac phenotype to prevent the complications in advance.

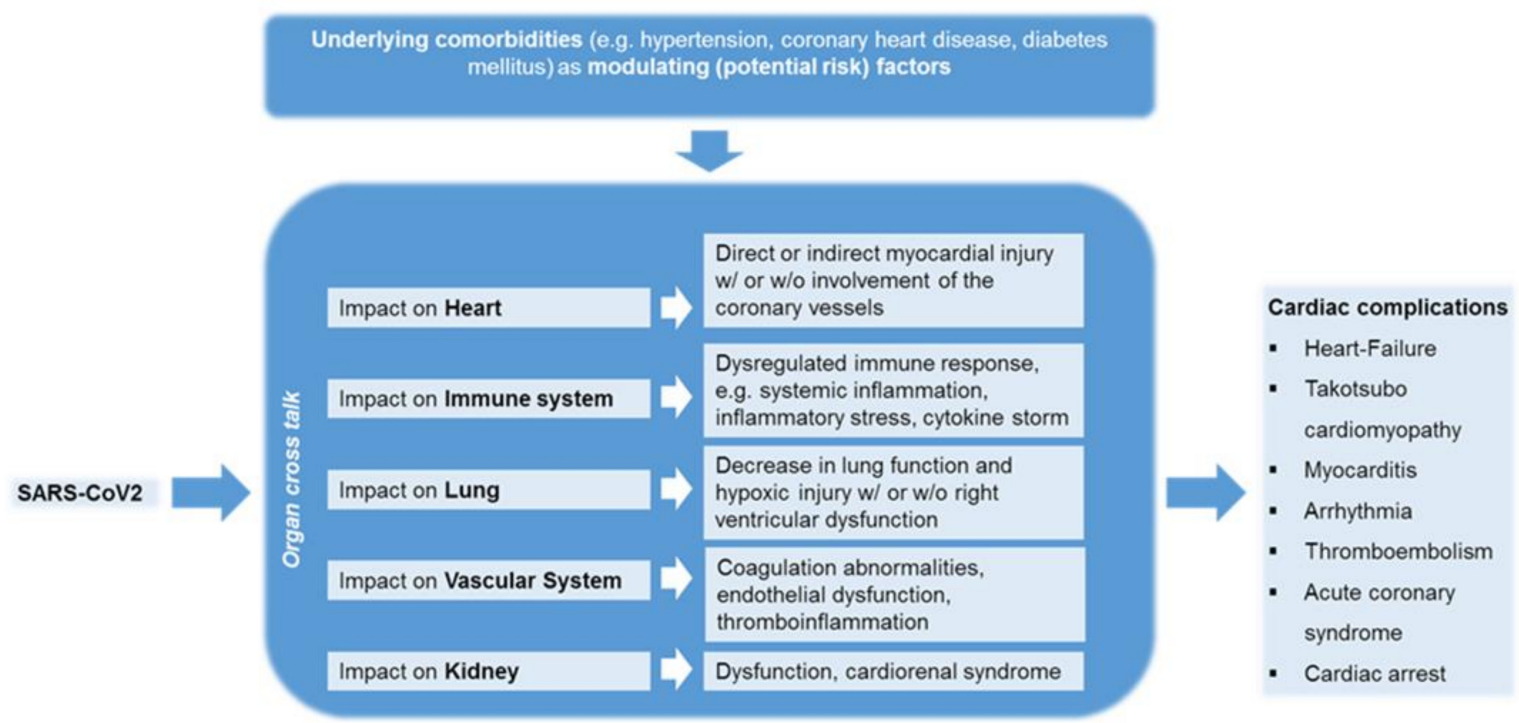

Figure 3. A crosstalk between the organs in inducing cardiac complications that are primarily triggered by SARS-CoV-2 virus among patients with underlying chronic conditions.

\section{Hypothetical Factors Beneath Asymptomatic COVID 19 Patients}

Despite patients with distinct symptoms during the course of COVID-19 disease, there are patients who do not exhibit any known signs of the disease and are therefore referred to as asymptomatic. Intriguingly, there are several hypotheses that support the symptomless nature of the disease, which are speculated to be determined by the host factors in terms of susceptibility to infection and the virus-related factors in terms of the degree of virulence. The host associated factors might include (i) insufficient expression of ACE2 receptors on nasopharynx or salivary glands, which could terminate in very feeble infection and could be unnoticed; (ii) polymorphisms in ACE2 gene, causing alteration in affinity binding region and spike protein processing [252]; (iii) polymorphism affecting TMPRSS2 structure and function; (iv) role of sex hormones, as women develop lesser complications than men [253]; (v) type of blood group, as people with A blood group are at higher risk compared to the people with O blood group [254]; (vi) alleles of major histocompatibility complex (MHC) class I, where the human leukocyte antigen (HLA)$B^{*} 46: 01$ tend to load fewer peptides and might increase the susceptibility to infection in comparison to HLA-B* 15:03 that enhance T cell immunity [255]; duration of antibodies production [256]. Likewise, the deletion of $15-30 \mathrm{bp}$ in the S1/S2 cleavage site region decreases the virulence of the SARS-CoV-2 virus $[257,258]$. 


\section{Different Models to Study the SARS-CoV-2 Virus Interaction with the Cardiovascular System}

Since most of the SARS-CoV-2 involved investigation with underlying cardiovascular complications is performed directly on the clinical specimens obtained from COVID-19 patients, a deeper gain in the knowledge for SARS-CoV-2 replication process and disease pathogenesis is required to achieve and design appropriate anti-SARS-CoV-2 targets. To fulfill the needs, suitable model systems still remain to be the major investigative tool, including 2 dimensional (2D) or 3D cell culture systems, organoids, and small or large animals [259]. Due to an increased viremia during the COVID-19 disease course, the blood vessels were presumed to be one of the main targets for the SARS-CoV-2 infection. For this purpose, blood capillary organoids were developed from induced pluripotent stem cells (iPSCs), which resembles native human capillary in terms of (i) CD31+ endothelial lining, (ii) PDGFR ${ }^{+}$pericytes, (iii) existence of lumen and (iv) formation of basal membrane. When these blood vessel organoids are infected with SARS-CoV-2 isolates, increasing viral RNA were detected that were amplified from day 3 to day 6 post-infection, indicating active SARS-CoV-2 virus replication. As expected, supernatants of these infected organoids harbored progeny virus which could efficiently infect the Vero E6 cells, implying the ability to form progeny viruses within capillary organoids. The kinetics of SARS-CoV-2 replication and progeny production were analyzed and subsequently targeted with biologicals such as human recombinant soluble ACE2, which in turn mitigated the SARS-CoV-2 infection [260]. Another study has demonstrated a competent establishment of SARS-CoV-2 infection in 2D human iPSCs-derived cardiomyocytes that expressed ACE2 receptors required for SARS-CoV-2 internalization by iPSC-cardiomyocytes. In addition to ACE2, the establishment of infection was also dependent on cathepsin. Evidence based data show that ACE2 expression is remarkably reduced in cardiomyocytes, upon SARS-CoV-2 infection. These SARS-CoV-2 infected iPSC-cardiomyocytes were subjected to apoptosis and ceased the beating in 72 hours post-infection, demonstrating cardiomyocyte-specific mechanisms induced by a SARS-CoV-2 virus [30]. Besides, this model has also revealed the effectiveness of an anti-viral drug, remdesivir, in curbing the infection. Further, the virus induced cardiotoxicity were also confirmed in a 3D cardiosphere model [31]. Of note, SARS-CoV-2 invasion exhibited cytopathogenic effects on iPSC- cardiomyocytes, inducing cell rounding, formation of grapelike clumps, and complete destruction of cell monolayers together with irreversible pyknotic cell shrinkage, which terminates in myocardial injuries. Furthermore, an array of cytokines and chemokines (IL-6, IL-8, tumor necrosis factor (TNF)- $\alpha$, CXCL1 and CXCL2) from iPSC-cardiomyocytes were released to assist further injury [261]. Recently employed drugs such as chloroquine (CQ) and azithromycin (AZM) to treat SARS-CoV-2 infection, were also tested on the human embryonic stem cell derived cardiomyocytes to investigate the drug induced cardiotoxicity, which reinforced the findings obtained from clinical data [262]. Apart, a demand for more complex physiological environment could be fulfilled using suitable animal models, including mice, humanized mice, hamsters, ferrets, non-human primates [259]. Since ferrets commonly develop cardiac diseases such as dilated cardiomyopathy, arrhythmias and ferret myocardium has positive force-frequency relationship (FFR) that is quite analogous to human [263], it represents a suitable model to investigate myocardial injury, induced during SARS-CoV-2 infection. Certain strains of Syrian hamster (Bio TO-2) exhibit progressive development of cardiac dysfunctions, including musculocutaneous blood flow associated with the cardiac remodeling that includes atrial hypertrophy and left ventricular dilation, wall thinning, increased collagen density, and decreased mean arterial pressure [264]. Furthermore, non-human primates, including rhesus and cynomologous macaques, are used as models to study the pathogenesis and progression of cardiovascular disease for several years [265]. In fact, ferrets, Syrian hamsters and macaques were shown to exhibit (i) susceptibility to SARS-CoV-2 infection, (ii) disease symptoms; (iii) a predicted binding affinity between SARS-CoV-2 virus and ACE2 receptors [266]. We, therefore, have briefly summarized 
possible models' systems that could be used in future to investigate SARS-CoV-2 associated mechanisms in general and also leading to cardiovascular complications.

\section{Possible Therapeutic Approaches against SARS-CoV-2 Induced Complications}

The availability of a single treatment regimen for mitigating the complications induced by the SARS-CoV-2 virus remains highly unattainable, as COVID-19 disease represents an assemblage of various complications involving vital organs, which have a deleterious impact on the biological system. Therefore, currently, a combination of several drugs is being administered to the patients suffering from COVID-19 disease that is mainly targeted with disease symptoms exhibited by every COVID 19 patient. Since the current review majorly focuses on the complexities involved in the vital organs such as heart and blood vessel, following SARS-CoV-2 infection, we summarize the possible drugs that improve the cardiac injury and vascular-related complications associated with SARS-CoV-2 infection. An anti-viral drug, Remdesivir, is an adenosine analogue that is embedded into the viral RNA chains to terminate in its premature form, resulting in SARS-CoV-2 replication inhibition [267]. It was effective and reduced the death, especially among those patients who were hypoxemic and supported with supplemental oxygen, but not among those with a mechanical ventilator [268]. This direct targeting of the SARS-CoV-2 virus might reduce the viral load and obviously, viral mediated damage to cardiac tissue. However, the management of severe hyper inflammation and hypercytokemia is pivotal to minimize the bystander effects induced by SARS-CoV-2, which accounts for increased cardiovascular complications and mortality in COVID-19 patients. Here, cytokine storm curbing can be achieved by administering humanized monoclonal antibodies against the IL-6 receptor (R), Tocilizumab and Sarilumab, which binds to membrane-bound IL-6R and also to soluble IL-6R. In addition, anti-IL-6 chimeric monoclonal antibodies, Siltuximab, are also given, which directly blocks the IL-6-associated inflammation, and thereby, these drugs improve the clinical outcome by controlling the body temperature together with improved peripheral oxygen saturation and minimized the inflammatory storm [269]. Moreover, there are several ongoing trials for COVID-19 patients to target the macrophage activation to reduce the hyper inflammation state inside the patients, where the drugs are targeted against other pro-inflammatory cytokines and chemokine such as IL-1ß, TNF- $\alpha$, IFN- $\gamma$ and CCR5 [270]. COVID-19 patients exhibiting hypoxemia are addressed with the supplemental oxygen support as an initial step during the hospitalization, though the type of support depends on the reported oxygen saturation [271]. Herewith improved hypoxemia of lungs among COVID-19 patients will further minimize the damage to vital organs, such as the heart. Next, COVID-19-associated coagulopathy remains to be a serious complication, leading to venous thromboembolism (VTE), where hospitalized adults with COVID-19 reported incidence of different thrombotic events, ranging between $7.7 \%$ and $49 \%$, which is unquestionably higher than the incidence in patients without COVID [272]. The development of thrombosis is considered to be a peculiar feature of the SARS-CoV-2 virus when binds to ACE2, which is expressed on platelets [117]. These hospitalized COVID-19 patients are recommended to take antithrombotic prophylaxis with low-molecular-weight heparin, unless there is a contraindication. Few clinical data have supported the use of fibrinolytic therapy, which might be beneficial in reducing death of COVID-19 patients with acute lung injury [272,273]. These recommendations of drugs for the above-mentioned complications induced by SARS-CoV-2 will certainly minimize the mortality rate [274], with a lesser burden on cardiovascular system, among COVID-19 patients.

\section{Conclusions}

Taken together, the SARS-CoV-2/receptor axis exerts a highly complex pathophysiological mechanism in heart tissues and blood vessel and associated cellular components, indicating SARS-CoV-2 mediated damage in terms of either aggravating the pre-existing cardiovascular conditions or generating a new onset of cardiac dysfunctions in non-chronic 
and naïve individuals, during the course of infection. Wide tissue expression of the SARSCoV-2 receptor system or multiple receptor targets to which the SARS-CoV-2 virus binds and facilitates its invasion to establish infection and viral dissemination are considered to be the key determinants for the majority of vital organ dysfunction and failure. This review comprehensively describes several possibly proven and hypothetical molecular mechanisms in cellular fractions of heart and vessel that are likely to occur during SARS-CoV-2 infection, in particular, causing heart failure and injuries to the vascular beds, mediated by host components in terms of vascular leakage and thrombotic events. This review also pinpoints the fact that the SARS-CoV-2/receptor axis plays a pan-pathogenic role in damaging every segment associated with safeguarding and well-functioning of the cardiovascular system. However, until-to-date, several SARS-CoV-2 induced pathomechanisms might either not be noticed properly or could possibly be overlooked due to our knowledge gaps. Since SARS-CoV-2 is a new and highly contagious life-threatening bug that has been unfortunately transmitted to the mankind, existing in the world, would still continue to pose many new unforeseen health challenges to all the affected individuals, which imparts high pressure to all the medical teams and research communities to make continuously strenuous efforts to combat the infection and to gain deeper understandings on the viralhost pathogenesis and to develop new therapeutic interventions, respectively. In order to prevent a complete damage to any vital organs, a thoughtful approach must be conducted through the surveillance and regular monitoring of all surviving individuals via continued follow-ups to prevent post-SARS-CoV-2 associated cardiovascular deteriorations. Further, treatment regimen could include blocking the SARS-CoV-2 receptors at the virus entry level or could minimize or improve vascular injuries by targeting leakage and coagulopathy, at the level of symptomatic disease outcome.

Funding: This research received no external funding.

Institutional Review Board Statement: Not applicable.

Informed Consent Statement: Not applicable.

Conflicts of Interest: All the authors declare no conflict of interest in this manuscript.

$\begin{array}{ll}\text { Abbreviations } \\ \text { COVID-19 } & \text { Coronavirus Disease-2019 } \\ \text { SARS-CoV-2 } & \text { Severe Acute Respiratory Syndr } \\ \text { WHO } & \text { World Health Organization } \\ \text { ACE2 } & \text { Angiotensin Converting Enzymes-2 } \\ \text { TMPRSS2 } & \text { Transmembrane Protease, Serine 2 } \\ \text { ECs } & \text { Endothelial Cells } \\ \text { ROS } & \text { Reactive Oxygen Species (ROS) } \\ \text { HIF-1 } \alpha & \text { Hypoxia Inducible Factor-1 alpha } \\ \text { STAT-1 } & \text { Signal transducer and activator of } \\ \text { IL } & \text { Interleukin } \\ \text { ADAM-17 } & \text { Action of a Disintegrin and Metallo } \\ \text { TNF- } \alpha & \text { Tumor Necrosis Factor-alpha } \\ \text { NOX } & \text { NADPH oxidase } \\ \text { PKR } & \text { Protein Kinase R } \\ \text { Nrf2 } & \text { Nuclear Factor E2-related Factor 2 } \\ \text { TLR } & \text { Toll-like Receptor } \\ \text { ROS } & \text { Reactive Oxygen Species } \\ \text { VCAM } & \text { Vascular Cell Adhesion Molecules } \\ \text { TACE } & \text { Tumor Necrosis Factor-a Converting Enz } \\ \text { RBD } & \text { Receptor Binding Domain } \\ \text { TGF- } \beta & \text { Transforming Growth Factor-Beta } \\ & \end{array}$




\begin{tabular}{|c|c|}
\hline RNA & Ribonucleic Acid \\
\hline RAS & Renin-Angiotensin System \\
\hline CAD & Coronary Artery Disease \\
\hline KKS & Kallikrein-Kinin System \\
\hline $\mathrm{B} 1 \mathrm{R}$ and $\mathrm{B} 2 \mathrm{R}$ & Bradykinin Receptors \\
\hline DR9-bradykinin & des-Arg-9-bradykinin \\
\hline $\mathrm{gC} 1 \mathrm{qR}$ & Globular C1q Receptor \\
\hline Ang II & Angiotensin II \\
\hline ICAM-1 & Intracellular Adhesion Molecules-1 \\
\hline HMWK & High Molecular Weight Kininogen \\
\hline NO & Nitric Oxide \\
\hline eNOS & endothelial nitric oxide synthase \\
\hline vWF & von Willebrand factor \\
\hline NETs & Neutrophil Extracellular Traps \\
\hline TF & Tissue Factor \\
\hline LDL & Low Density Lipoproteins \\
\hline PAI-1 & Plasminogen Activator Inhibitor-1 \\
\hline WPBs & Weibel-Palade bodies \\
\hline $\mathrm{ZO}$ & Zonula Occludens \\
\hline DIC & Disseminated Intravascular Coagulation \\
\hline PS & phosphatidylserine \\
\hline RBCs & Red Blood Cells \\
\hline EPCR & Endothelial Cell Protein C Receptor \\
\hline NLRP3 & NLRP- NLR family pyrin domain contain \\
\hline IP-10 & Interferon gamma-induced protein 10 \\
\hline CS & contact system \\
\hline FasR & FS-7-associated surface antigen Recept \\
\hline iPSCs & Induced Pluripotent Stem Cell \\
\hline VTE & Venous Thromboembolism \\
\hline MCP-1 & MCP-1-monocyte chemoattractant prote \\
\hline OHCA & Out-of-Hospital Cardiac Arrest \\
\hline IHCA & In-of-Hospital Cardiac Arrest \\
\hline VEGF & Vascular endothelial Growth Factor \\
\hline IFN- $\gamma$ & Interferon-gamma \\
\hline GM-CSF & Granulocyte-Monocyte Colony Stimulatin \\
\hline
\end{tabular}

\section{References}

1. Wu, C.; Chen, X.; Cai, Y.; Xia, J.; Zhou, X.; Xu, S.; Huang, H.; Zhang, L.; Zhou, X.; Du, C.; et al. Risk Factors Associated With Acute Respiratory Distress Syndrome and Death in Patients With Coronavirus Disease 2019 Pneumonia in Wuhan, China. JAMA Intern. Med. 2020, 180, 934-943. [CrossRef] [PubMed]

2. Cucinotta, D.; Vanelli, M. WHO Declares COVID-19 a Pandemic. Acta Biomed. Atenei Parm. 2020, 91, 157-160.

3. Zhu, N.; Zhang, D.; Wang, W.; Li, X.; Yang, B.; Song, J.; Zhao, X.; Huang, B.; Shi, W.; Lu, R.; et al. A Novel Coronavirus from Patients with Pneumonia in China, 2019. N. Engl. J. Med. 2020, 382, 727-733. [CrossRef]

4. Li, Q.; Guan, X.; Wu, P.; Wang, X.; Zhou, L.; Tong, Y.; Ren, R.; Leung, K.S.M.; Lau, E.H.Y.; Wong, J.Y.; et al. Early Transmission Dynamics in Wuhan, China, of Novel Coronavirus-Infected Pneumonia. N. Engl. J. Med. 2020, 382, 1199-1207. [CrossRef] [PubMed]

5. Wang, Q.; Zhang, Y.; Wu, L.; Niu, S.; Song, C.; Zhang, Z.; Lu, G.; Qiao, C.; Hu, Y.; Yuen, K.Y.; et al. Structural and Functional Basis of SARS-CoV-2 Entry by Using Human ACE2. Cell 2020, 181, 894-904.e9. [CrossRef] [PubMed]

6. Hoffmann, M.; Kleine-Weber, H.; Pöhlmann, S. A Multibasic Cleavage Site in the Spike Protein of SARS-CoV-2 Is Essential for Infection of Human Lung Cells. Mol. Cell 2020, 78, 779-784.e5. [CrossRef]

7. Lukassen, S.; Chua, R.L.; Trefzer, T.; Kahn, N.C.; Schneider, M.A.; Muley, T.; Winter, H.; Meister, M.; Veith, C.; Boots, A.W.; et al. SARS-CoV-2 receptor ACE2 and TMPRSS2 are primarily expressed in bronchial transient secretory cells. EMBO J. 2020, 39, e105114. [CrossRef]

8. Zhao, M.M.; Yang, W.L.; Yang, F.Y.; Zhang, L.; Huang, W.J.; Hou, W.; Fan, C.F.; Jin, R.H.; Feng, Y.M.; Wang, Y.C.; et al. Cathepsin L plays a key role in SARS-CoV-2 infection in humans and humanized mice and is a promising target for new drug development. Signal Transduct. Target. Ther. 2021, 6, 134. [CrossRef]

9. Zhong, M.; Lin, B.; Pathak, J.L.; Gao, H.; Young, A.J.; Wang, X.; Liu, C.; Wu, K.; Liu, M.; Chen, J.M.; et al. ACE2 and Furin Expressions in Oral Epithelial Cells Possibly Facilitate COVID-19 Infection via Respiratory and Fecal-Oral Routes. Front. Med. 2020, 7, 580796. [CrossRef] 
10. Wang, S.; Qiu, Z.; Hou, Y.; Deng, X.; Xu, W.; Zheng, T.; Wu, P.; Xie, S.; Bian, W.; Zhang, C.; et al. AXL is a candidate receptor for SARS-CoV-2 that promotes infection of pulmonary and bronchial epithelial cells. Cell Res. 2021, 31, 126-140. [CrossRef]

11. Huang, Y.; Yang, C.; Xu, X.F.; Xu, W.; Liu, S.W. Structural and functional properties of SARS-CoV-2 spike protein: Potential antivirus drug development for COVID-19. Acta Pharmacol. Sin. 2020, 41, 1141-1149. [CrossRef] [PubMed]

12. Hamming, I.; Timens, W.; Bulthuis, M.L.; Lely, A.T.; Navis, G.; van Goor, H. Tissue distribution of ACE2 protein, the functional receptor for SARS coronavirus. A first step in understanding SARS pathogenesis. J. Pathol. 2004, 203, 631-637. [CrossRef] [PubMed]

13. Zou, X.; Chen, K.; Zou, J.; Han, P.; Hao, J.; Han, Z. Single-cell RNA-seq data analysis on the receptor ACE2 expression reveals the potential risk of different human organs vulnerable to 2019-nCoV infection. Front. Med. 2020, 14, 185-192. [CrossRef]

14. Velavan, T.P.; Meyer, C.G. Mild versus severe COVID-19: Laboratory markers. Int. J. Infect. Dis. 2020, 95, 304-307. [CrossRef]

15. Nishiga, M.; Wang, D.W.; Han, Y.; Lewis, D.B.; Wu, J.C. COVID-19 and cardiovascular disease: From basic mechanisms to clinical perspectives. Nat. Rev. Cardiol. 2020, 17, 543-558. [CrossRef]

16. Litviňuková, M.; Talavera-López, C.; Maatz, H.; Reichart, D.; Worth, C.L.; Lindberg, E.L.; Kanda, M.; Polanski, K.; Heinig, M.; Lee, M.; et al. Cells of the adult human heart. Nature 2020, 588, 466-472. [CrossRef]

17. Liu, H.; Gai, S.; Wang, X.; Zeng, J.; Sun, C.; Zhao, Y.; Zheng, Z. Single-cell analysis of SARS-CoV-2 receptor ACE2 and spike protein priming expression of proteases in the human heart. Cardiovasc. Res. 2020, 116, 1733-1741. [CrossRef]

18. Nicin, L.; Abplanalp, W.T.; Mellentin, H.; Kattih, B.; Tombor, L.; John, D.; Schmitto, J.D.; Heineke, J.; Emrich, F.; Arsalan, M.; et al. Cell type-specific expression of the putative SARS-CoV-2 receptor ACE2 in human hearts. Eur. Heart J. 2020, 41, 1804-1806. [CrossRef] [PubMed]

19. Chen, L.; Li, X.; Chen, M.; Feng, Y.; Xiong, C. The ACE2 expression in human heart indicates new potential mechanism of heart injury among patients infected with SARS-CoV-2. Cardiovasc. Res. 2020, 116, 1097-1100. [CrossRef] [PubMed]

20. Sakamoto, A.; Kawakami, R.; Kawai, K.; Gianatti, A.; Pellegrini, D.; Kutys, R.; Guo, L.; Mori, M.; Cornelissen, A.; Sato, Y.; et al. ACE2 (Angiotensin-Converting Enzyme 2) and TMPRSS2 (Transmembrane Serine Protease 2) Expression and Localization of SARS-CoV-2 Infection in the Human Heart. Arterioscler. Thromb. Vasc. Biol. 2021, 41, 542-544. [CrossRef] [PubMed]

21. Gkogkou, E.; Barnasas, G.; Vougas, K.; Trougakos, I.P. Expression profiling meta-analysis of ACE2 and TMPRSS2, the putative anti-inflammatory receptor and priming protease of SARS-CoV-2 in human cells, and identification of putative modulators. Redox Biol. 2020, 36, 101615. [CrossRef]

22. Batlle, M.; Recarte-Pelz, P.; Roig, E.; Castel, M.A.; Cardona, M.; Farrero, M.; Ortiz, J.T.; Campos, B.; Pulgarín, M.J.; Ramírez, J.; et al. AXL receptor tyrosine kinase is increased in patients with heart failure. Int. J. Cardiol. 2014, 173, 402-409. [CrossRef]

23. DeBerge, M.; Glinton, K.; Subramanian, M.; Wilsbacher, L.D.; Rothlin, C.V.; Tabas, I.; Thorp, E.B. Macrophage AXL receptor tyrosine kinase inflames the heart after reperfused myocardial infarction. J. Clin. Investig. 2021, 131. [CrossRef]

24. Codo, A.C.; Davanzo, G.G.; Monteiro, L.B.; de Souza, G.F.; Muraro, S.P.; Virgilio-da-Silva, J.V.; Prodonoff, J.S.; Carregari, V.C.; de Biagi Junior, C.A.O.; Crunfli, F.; et al. Elevated Glucose Levels Favor SARS-CoV-2 Infection and Monocyte Response through a HIF-1 $\alpha$ /Glycolysis-Dependent Axis. Cell Metab. 2020, 32, 437-446.e5. [CrossRef] [PubMed]

25. Matsuyama, T.; Kubli, S.P.; Yoshinaga, S.K.; Pfeffer, K.; Mak, T.W. An aberrant STAT pathway is central to COVID-19. Cell Death Differ. 2020, 27, 3209-3225. [CrossRef] [PubMed]

26. Bulfamante, G.P.; Perrucci, G.L.; Falleni, M.; Sommariva, E.; Tosi, D.; Martinelli, C.; Songia, P.; Poggio, P.; Carugo, S.; Pompilio, G. Evidence of SARS-CoV-2 Transcriptional Activity in Cardiomyocytes of COVID-19 Patients without Clinical Signs of Cardiac Involvement. Biomedicines 2020, 8, 626. [CrossRef]

27. Dolhnikoff, M.; Ferreira Ferranti, J.; de Almeida Monteiro, R.A.; Duarte-Neto, A.N.; Soares Gomes-Gouvêa, M.; Viu Degaspare, N.; Figueiredo Delgado, A.; Montanari Fiorita, C.; Nunes Leal, G.; Rodrigues, R.M.; et al. SARS-CoV-2 in cardiac tissue of a child with COVID-19-related multisystem inflammatory syndrome. Lancet. Child Adolesc. Health 2020, 4, 790-794. [CrossRef]

28. Li, N.; Zhu, L.; Sun, L.; Shao, G. The effects of novel coronavirus (SARS-CoV-2) infection on cardiovascular diseases and cardiopulmonary injuries. Stem Cell Res. 2021, 51, 102168. [CrossRef] [PubMed]

29. Adeghate, E.A.; Eid, N.; Singh, J. Mechanisms of COVID-19-induced heart failure: A short review. Heart Fail. Rev. 2021, 26, 363-369. [CrossRef]

30. Sharma, A.; Garcia, G., Jr.; Wang, Y.; Plummer, J.T.; Morizono, K.; Arumugaswami, V.; Svendsen, C.N. Human iPSC-Derived Cardiomyocytes Are Susceptible to SARS-CoV-2 Infection. Cell Rep. Med. 2020, 1, 100052. [CrossRef]

31. Bojkova, D.; Wagner, J.U.; Shumliakivska, M.; Aslan, G.S.; Saleem, U.; Hansen, A.; Luxán, G.; Günther, S.; Pham, M.D.; Krishnan, J.; et al. SARS-CoV-2 infects and induces cytotoxic effects in human cardiomyocytes. Cardiovasc. Res. 2020, 116, 2207-2215. [CrossRef]

32. Li, Y.; Renner, D.M.; Comar, C.E.; Whelan, J.N.; Reyes, H.M.; Cardenas-Diaz, F.L.; Truitt, R.; Tan, L.H.; Dong, B.; Alysandratos, K.D.; et al. SARS-CoV-2 induces double-stranded RNA-mediated innate immune responses in respiratory epithelial-derived cells and cardiomyocytes. Proc. Natl. Acad. Sci. USA 2021, 118, e2022643118. [CrossRef] [PubMed]

33. Khomich, O.A.; Kochetkov, S.N.; Bartosch, B.; Ivanov, A.V. Redox Biology of Respiratory Viral Infections. Viruses 2018, 10, 392. [CrossRef] [PubMed]

34. Violi, F.; Pastori, D.; Pignatelli, P.; Cangemi, R. SARS-CoV-2 and myocardial injury: A role for Nox2? Intern. Emerg. Med. 2020, 15, 755-758. [CrossRef] 
35. Olagnier, D.; Farahani, E.; Thyrsted, J.; Blay-Cadanet, J.; Herengt, A.; Idorn, M.; Hait, A.; Hernaez, B.; Knudsen, A.; Iversen, M.B.; et al. SARS-CoV2-mediated suppression of NRF2-signaling reveals potent antiviral and anti-inflammatory activity of 4-octylitaconate and dimethyl fumarate. Nat. Commun. 2020, 11, 4938. [CrossRef]

36. Damiano, S.; Sozio, C.; La Rosa, G.; Santillo, M. NOX-Dependent Signaling Dysregulation in Severe COVID-19: Clues to Effective Treatments. Front. Cell. Infect. Microbiol. 2020, 10, 608435. [CrossRef]

37. Burrell, L.M.; Johnston, C.I.; Tikellis, C.; Cooper, M.E. ACE2, a new regulator of the renin-angiotensin system. Trends Endocrinol. Metab. TEM 2004, 15, 166-169. [CrossRef]

38. Gue, Y.X.; Gorog, D.A. Reduction in ACE2 may mediate the prothrombotic phenotype in COVID-19. Eur. Heart J. 2020, 41, 3198-3199. [CrossRef] [PubMed]

39. Patel, V.B.; Zhong, J.C.; Grant, M.B.; Oudit, G.Y. Role of the ACE2/Angiotensin 1-7 Axis of the Renin-Angiotensin System in Heart Failure. Circ. Res. 2016, 118, 1313-1326. [CrossRef] [PubMed]

40. Zhang, Y.H.; Zhang, Y.H.; Dong, X.F.; Hao, Q.Q.; Zhou, X.M.; Yu, Q.T.; Li, S.Y.; Chen, X.; Tengbeh, A.F.; Dong, B.; et al. ACE2 and Ang-(1-7) protect endothelial cell function and prevent early atherosclerosis by inhibiting inflammatory response. Inflamm. Res. 2015, 64, 253-260. [CrossRef] [PubMed]

41. Lovren, F.; Pan, Y.; Quan, A.; Teoh, H.; Wang, G.; Shukla, P.C.; Levitt, K.S.; Oudit, G.Y.; Al-Omran, M.; Stewart, D.J.; et al. Angiotensin converting enzyme-2 confers endothelial protection and attenuates atherosclerosis. Am. J. Physiol. Heart Circ. Physiol. 2008, 295, H1377-H1384. [CrossRef]

42. Ushio-Fukai, M.; Zafari, A.M.; Fukui, T.; Ishizaka, N.; Griendling, K.K. p22phox is a critical component of the superoxidegenerating NADH/NADPH oxidase system and regulates angiotensin II-induced hypertrophy in vascular smooth muscle cells. J. Biol. Chem. 1996, 271, 23317-23321. [CrossRef] [PubMed]

43. Chen, J.; Xiao, X.; Chen, S.; Zhang, C.; Chen, J.; Yi, D.; Shenoy, V.; Raizada, M.K.; Zhao, B.; Chen, Y. Angiotensin-converting enzyme 2 priming enhances the function of endothelial progenitor cells and their therapeutic efficacy. Hypertension 2013, 61, 681-689. [CrossRef]

44. Rodrigues Prestes, T.R.; Rocha, N.P.; Miranda, A.S.; Teixeira, A.L.; Simoes, E.S.A.C. The Anti-Inflammatory Potential of ACE2/Angiotensin-(1-7)/Mas Receptor Axis: Evidence from Basic and Clinical Research. Curr. Drug Targets 2017, 18, 1301-1313. [CrossRef] [PubMed]

45. Jiang, T.; Gao, L.; Lu, J.; Zhang, Y.D. ACE2-Ang-(1-7)-Mas Axis in Brain: A Potential Target for Prevention and Treatment of Ischemic Stroke. Curr. Neuropharmacol. 2013, 11, 209-217. [CrossRef] [PubMed]

46. Fang, C.; Stavrou, E.; Schmaier, A.A.; Grobe, N.; Morris, M.; Chen, A.; Nieman, M.T.; Adams, G.N.; LaRusch, G.; Zhou, Y.; et al. Angiotensin 1-7 and Mas decrease thrombosis in Bdkrb2 ${ }^{-/-}$mice by increasing NO and prostacyclin to reduce platelet spreading and glycoprotein VI activation. Blood 2013, 121, 3023-3032. [CrossRef]

47. Thatcher, S.E.; Zhang, X.; Howatt, D.A.; Lu, H.; Gurley, S.B.; Daugherty, A.; Cassis, L.A. Angiotensin-converting enzyme 2 deficiency in whole body or bone marrow-derived cells increases atherosclerosis in low-density lipoprotein receptor-/- mice. Arterioscler. Thromb. Vasc. Biol. 2011, 31, 758-765. [CrossRef] [PubMed]

48. Xu, B.; Li, G.; Guo, J.; Ikezoe, T.; Kasirajan, K.; Zhao, S.; Dalman, R.L. Angiotensin-converting enzyme 2, coronavirus disease 2019, and abdominal aortic aneurysms. J. Vasc. Surg. 2021. [CrossRef]

49. Liu, A.; Zhang, X.; Li, R.; Zheng, M.; Yang, S.; Dai, L.; Wu, A.; Hu, C.; Huang, Y.; Xie, M.; et al. Overexpression of the SARS-CoV-2 receptor ACE2 is induced by cigarette smoke in bronchial and alveolar epithelia. J. Pathol. 2021, 253, 17-30. [CrossRef]

50. Chiang, A.W.T.; Duong, L.D.; Shoda, T.; Nhu, Q.M.; Ruffner, M.; Hara, T.; Aaron, B.; Joplin, E.; Manresa, M.C.; Abonia, J.P.; et al. Type 2 Immunity and Age Modify Gene Expression of Coronavirus-induced Disease 2019 Receptors in Eosinophilic Gastrointestinal Disorders. J. Pediatric Gastroenterol. Nutr. 2021, 72, 718-722. [CrossRef]

51. Lambert, D.W.; Yarski, M.; Warner, F.J.; Thornhill, P.; Parkin, E.T.; Smith, A.I.; Hooper, N.M.; Turner, A.J. Tumor necrosis factoralpha convertase (ADAM17) mediates regulated ectodomain shedding of the severe-acute respiratory syndrome-coronavirus (SARS-CoV) receptor, angiotensin-converting enzyme-2 (ACE2). J. Biol. Chem. 2005, 280, 30113-30119. [CrossRef]

52. Lambert, D.W.; Clarke, N.E.; Hooper, N.M.; Turner, A.J. Calmodulin interacts with angiotensin-converting enzyme-2 (ACE2) and inhibits shedding of its ectodomain. FEBS Lett. 2008, 582, 385-390. [CrossRef] [PubMed]

53. Epelman, S.; Tang, W.H.; Chen, S.Y.; Van Lente, F.; Francis, G.S.; Sen, S. Detection of soluble angiotensin-converting enzyme 2 in heart failure: Insights into the endogenous counter-regulatory pathway of the renin-angiotensin-aldosterone system. J. Am. Coll. Cardiol. 2008, 52, 750-754. [CrossRef]

54. Fagyas, M.; Kertész, A.; Siket, I.M.; Bánhegyi, V.; Kracskó, B.; Szegedi, A.; Szokol, M.; Vajda, G.; Rácz, I.; Gulyás, H.; et al. Level of the SARS-CoV-2 receptor ACE2 activity is highly elevated in old-aged patients with aortic stenosis: Implications for ACE2 as a biomarker for the severity of COVID-19. GeroScience 2021, 43, 19-29. [CrossRef]

55. Ramchand, J.; Patel, S.K.; Kearney, L.G.; Matalanis, G.; Farouque, O.; Srivastava, P.M.; Burrell, L.M. Plasma ACE2 Activity Predicts Mortality in Aortic Stenosis and Is Associated With Severe Myocardial Fibrosis. JACC. Cardiovasc. Imaging 2020, 13, 655-664. [CrossRef] [PubMed]

56. Ramchand, J.; Patel, S.K.; Srivastava, P.M.; Farouque, O.; Burrell, L.M. Elevated plasma angiotensin converting enzyme 2 activity is an independent predictor of major adverse cardiac events in patients with obstructive coronary artery disease. PLoS ONE 2018, 13, e0198144. [CrossRef] [PubMed] 
57. Narula, S.; Yusuf, S.; Chong, M.; Ramasundarahettige, C.; Rangarajan, S.; Bangdiwala, S.I.; van Eikels, M.; Leineweber, K.; Wu, A.; Pigeyre, M.; et al. Plasma ACE2 and risk of death or cardiometabolic diseases: A case-cohort analysis. Lancet 2020, 396, 968-976. [CrossRef]

58. Wysocki, J.; Ye, M.; Rodriguez, E.; González-Pacheco, F.R.; Barrios, C.; Evora, K.; Schuster, M.; Loibner, H.; Brosnihan, K.B.; Ferrario, C.M.; et al. Targeting the degradation of angiotensin II with recombinant angiotensin-converting enzyme 2: Prevention of angiotensin II-dependent hypertension. Hypertension 2010, 55, 90-98. [CrossRef] [PubMed]

59. Abd El-Aziz, T.M.; Al-Sabi, A.; Stockand, J.D. Human recombinant soluble ACE2 (hrsACE2) shows promise for treating severe COVID-19. Signal Transduct. Target. Ther. 2020, 5, 258. [CrossRef]

60. Wysocki, J.; Schulze, A.; Batlle, D. Novel Variants of Angiotensin Converting Enzyme-2 of Shorter Molecular Size to Target the Kidney Renin Angiotensin System. Biomolecules 2019, 9, 886. [CrossRef]

61. Wysocki, J.; Ye, M.; Hassler, L.; Gupta, A.K.; Wang, Y.; Nicoleascu, V.; Randall, G.; Wertheim, J.A.; Batlle, D. A Novel Soluble ACE2 Variant with Prolonged Duration of Action Neutralizes SARS-CoV-2 Infection in Human Kidney Organoids. J. Am. Soc. Nephrol. 2021, 32, 795-803. [CrossRef] [PubMed]

62. Hussain, M.; Jabeen, N.; Raza, F.; Shabbir, S.; Baig, A.A.; Amanullah, A.; Aziz, B. Structural variations in human ACE2 may influence its binding with SARS-CoV-2 spike protein. J. Med Virol. 2020, 92, 1580-1586. [CrossRef] [PubMed]

63. Liu, S.; DeLalio, L.J.; Isakson, B.E.; Wang, T.T. AXL-Mediated Productive Infection of Human Endothelial Cells by Zika Virus. Circ. Res. 2016, 119, 1183-1189. [CrossRef]

64. Hoffmann, M.; Kleine-Weber, H.; Schroeder, S.; Krüger, N.; Herrler, T.; Erichsen, S.; Schiergens, T.S.; Herrler, G.; Wu, N.H.; Nitsche, A.; et al. SARS-CoV-2 Cell Entry Depends on ACE2 and TMPRSS2 and Is Blocked by a Clinically Proven Protease Inhibitor. Cell 2020, 181, 271-280.e8. [CrossRef]

65. Lee, M.H.; Perl, D.P.; Nair, G.; Li, W.; Maric, D.; Murray, H.; Dodd, S.J.; Koretsky, A.P.; Watts, J.A.; Cheung, V.; et al. Microvascular Injury in the Brains of Patients with Covid-19. N. Engl. J. Med. 2021, 384, 481-483. [CrossRef] [PubMed]

66. Conklin, J.; Frosch, M.P.; Mukerji, S.; Rapalino, O.; Maher, M.; Schaefer, P.W.; Lev, M.H.; Gonzalez, R.G.; Das, S.; Champion, S.N.; et al. Cerebral Microvascular Injury in Severe COVID-19. medRxiv 2020. [CrossRef]

67. Kim, Y.H.; Nijst, P.; Kiefer, K.; Tang, W.H. Endothelial Glycocalyx as Biomarker for Cardiovascular Diseases: Mechanistic and Clinical Implications. Curr. Heart Fail. Rep. 2017, 14, 117-126. [CrossRef]

68. Lopatko Fagerström, I.; Ståhl, A.L.; Mossberg, M.; Tati, R.; Kristoffersson, A.C.; Kahn, R.; Bascands, J.L.; Klein, J.; Schanstra, J.P.; Segelmark, M.; et al. Blockade of the kallikrein-kinin system reduces endothelial complement activation in vascular inflammation. EBioMedicine 2019, 47, 319-328. [CrossRef]

69. Curry, F.E. Layer upon layer: The functional consequences of disrupting the glycocalyx-endothelial barrier in vivo and in vitro. Cardiovasc. Res. 2017, 113, 559-561. [CrossRef]

70. Machin, D.R.; Phuong, T.T.; Donato, A.J. The role of the endothelial glycocalyx in advanced age and cardiovascular disease. Curr. Opin. Pharmacol. 2019, 45, 66-71. [CrossRef]

71. Yamaoka-Tojo, M. Endothelial glycocalyx damage as a systemic inflammatory microvascular endotheliopathy in COVID-19. Biomed. J. 2020, 43, 399-413. [CrossRef] [PubMed]

72. Yamaoka-Tojo, M. Vascular Endothelial Glycocalyx Damage in COVID-19. Int. J. Mol. Sci. 2020, 21, 9712. [CrossRef]

73. Prydz, K. Determinants of Glycosaminoglycan (GAG) Structure. Biomolecules 2015, 5, 2003-2022. [CrossRef] [PubMed]

74. Zhang, Q.; Chen, C.Z.; Swaroop, M.; Xu, M.; Wang, L.; Lee, J.; Wang, A.Q.; Pradhan, M.; Hagen, N.; Chen, L.; et al. Heparan sulfate assists SARS-CoV-2 in cell entry and can be targeted by approved drugs in vitro. Cell Discov. 2020, 6, 80. [CrossRef] [PubMed]

75. Cecchini, R.; Cecchini, A.L. SARS-CoV-2 infection pathogenesis is related to oxidative stress as a response to aggression. Med. Hypotheses 2020, 143, 110102. [CrossRef]

76. Alsaffar, H.; Martino, N.; Garrett, J.P.; Adam, A.P. Interleukin-6 promotes a sustained loss of endothelial barrier function via Janus kinase-mediated STAT3 phosphorylation and de novo protein synthesis. Am. J. Physiol. Cell Physiol. 2018, 314, C589-C602. [CrossRef]

77. Potje, S.R.; Paula, T.D.; Paulo, M.; Bendhack, L.M. The Role of Glycocalyx and Caveolae in Vascular Homeostasis and Diseases. Front. Physiol. 2020, 11, 620840. [CrossRef]

78. van de Veerdonk, F.L.; Netea, M.G.; van Deuren, M.; van der Meer, J.W.; de Mast, Q.; Brüggemann, R.J.; van der Hoeven, H. Kallikrein-kinin blockade in patients with COVID-19 to prevent acute respiratory distress syndrome. eLife 2020, 9, e57555. [CrossRef]

79. Hilgenfeldt, U.; Puschner, T.; Riester, U.; Finsterle, J.; Hilgenfeldt, J.; Ritz, E. Low-salt diet downregulates plasma but not tissue kallikrein-kinin system. Am. J. Physiol. 1998, 275, F88-F93. [CrossRef]

80. Schmaier, A.H. The contact activation and kallikrein/kinin systems: Pathophysiologic and physiologic activities. J. Thromb. Haemost. 2016, 14, 28-39. [CrossRef]

81. Bryant, J.W.; Shariat-Madar, Z. Human plasma kallikrein-kinin system: Physiological and biochemical parameters. Cardiovasc. Hematol. Agents Med. Chem. 2009, 7, 234-250. [CrossRef] [PubMed]

82. Mahdi, F.; Madar, Z.S.; Figueroa, C.D.; Schmaier, A.H. Factor XII interacts with the multiprotein assembly of urokinase plasminogen activator receptor, gC1qR, and cytokeratin 1 on endothelial cell membranes. Blood 2002, 99, 3585-3596. [CrossRef] [PubMed] 
83. Shariat-Madar, Z.; Mahdi, F.; Schmaier, A.H. Recombinant prolylcarboxypeptidase activates plasma prekallikrein. Blood 2004, 103, 4554-4561. [CrossRef]

84. Zhao, Y.; Qiu, Q.; Mahdi, F.; Shariat-Madar, Z.; Røjkjaer, R.; Schmaier, A.H. Assembly and activation of HK-PK complex on endothelial cells results in bradykinin liberation and NO formation. Am. J. Physiol. Heart Circ. Physiol. 2001, 280, H1821-H1829. [CrossRef] [PubMed]

85. Sodhi, C.P.; Wohlford-Lenane, C.; Yamaguchi, Y.; Prindle, T.; Fulton, W.B.; Wang, S.; McCray, P.B., Jr.; Chappell, M.; Hackam, D.J.; Jia, H. Attenuation of pulmonary ACE2 activity impairs inactivation of des-Arg(9) bradykinin/BKB1R axis and facilitates LPS-induced neutrophil infiltration. Am. J. Physiol. Lung Cell. Mol. Physiol. 2018, 314, L17-L31. [CrossRef] [PubMed]

86. Shen, B.; El-Dahr, S.S. Cross-talk of the renin-angiotensin and kallikrein-kinin systems. Biol. Chem. 2006, 387, 145-150. [CrossRef]

87. Chen, Z.; Deddish, P.A.; Minshall, R.D.; Becker, R.P.; Erdös, E.G.; Tan, F. Human ACE and bradykinin B2 receptors form a complex at the plasma membrane. FASEB J. 2006, 20, 2261-2270. [CrossRef] [PubMed]

88. Ruiz, S.; Vardon-Bounes, F.; Buléon, M.; Guilbeau-Frugier, C.; Séguelas, M.H.; Conil, J.M.; Girolami, J.P.; Tack, I.; Minville, V. Kinin B1 receptor: A potential therapeutic target in sepsis-induced vascular hyperpermeability. J. Transl. Med. 2020, 18, 174. [CrossRef]

89. Mugisho, O.O.; Robilliard, L.D.; Nicholson, L.F.B.; Graham, E.S.; O'Carroll, S.J. Bradykinin receptor-1 activation induces inflammation and increases the permeability of human brain microvascular endothelial cells. Cell Biol. Int. 2019. [CrossRef] [PubMed]

90. Klok, F.A.; Kruip, M.; van der Meer, N.J.M.; Arbous, M.S.; Gommers, D.; Kant, K.M.; Kaptein, F.H.J.; van Paassen, J.; Stals, M.A.M.; Huisman, M.V.; et al. Incidence of thrombotic complications in critically ill ICU patients with COVID-19. Thromb. Res. 2020, 191, 145-147. [CrossRef] [PubMed]

91. Poissy, J.; Goutay, J.; Caplan, M.; Parmentier, E.; Duburcq, T.; Lassalle, F.; Jeanpierre, E.; Rauch, A.; Labreuche, J.; Susen, S.; et al. Pulmonary Embolism in Patients with COVID-19: Awareness of an Increased Prevalence. Circulation 2020, 142, 184-186. [CrossRef] [PubMed]

92. Middeldorp, S.; Coppens, M.; van Haaps, T.F.; Foppen, M.; Vlaar, A.P.; Müller, M.C.A.; Bouman, C.C.S.; Beenen, L.F.M.; Kootte, R.S.; Heijmans, J.; et al. Incidence of venous thromboembolism in hospitalized patients with COVID-19. J. Thromb. Haemost. 2020, 18, 1995-2002. [CrossRef] [PubMed]

93. Hanify, J.M.; Dupree, L.H.; Johnson, D.W.; Ferreira, J.A. Failure of chemical thromboprophylaxis in critically ill medical and surgical patients with sepsis. J. Crit. Care 2017, 37, 206-210. [CrossRef]

94. Llitjos, J.F.; Leclerc, M.; Chochois, C.; Monsallier, J.M.; Ramakers, M.; Auvray, M.; Merouani, K. High incidence of venous thromboembolic events in anticoagulated severe COVID-19 patients. J. Thromb. Haemost. 2020, 18, 1743-1746. [CrossRef] [PubMed]

95. Panigada, M.; Bottino, N.; Tagliabue, P.; Grasselli, G.; Novembrino, C.; Chantarangkul, V.; Pesenti, A.; Peyvandi, F.; Tripodi, A. Hypercoagulability of COVID-19 patients in intensive care unit: A report of thromboelastography findings and other parameters of hemostasis. J. Thromb. Haemost. 2020, 18, 1738-1742. [CrossRef]

96. Spiezia, L.; Boscolo, A.; Poletto, F.; Cerruti, L.; Tiberio, I.; Campello, E.; Navalesi, P.; Simioni, P. COVID-19-Related Severe Hypercoagulability in Patients Admitted to Intensive Care Unit for Acute Respiratory Failure. Thromb. Haemost. 2020, 120, 998-1000. [CrossRef]

97. Ackermann, M.; Verleden, S.E.; Kuehnel, M.; Haverich, A.; Welte, T.; Laenger, F.; Vanstapel, A.; Werlein, C.; Stark, H.; Tzankov, A.; et al. Pulmonary Vascular Endothelialitis, Thrombosis, and Angiogenesis in Covid-19. N. Engl. J. Med. 2020, 383, 120-128. [CrossRef] [PubMed]

98. Han, H.; Yang, L.; Liu, R.; Liu, F.; Wu, K.L.; Li, J.; Liu, X.H.; Zhu, C.L. Prominent changes in blood coagulation of patients with SARS-CoV-2 infection. Clin. Chem. Lab. Med. 2020, 58, 1116-1120. [CrossRef]

99. Guan, W.J.; Ni, Z.Y.; Hu, Y.; Liang, W.H.; Ou, C.Q.; He, J.X.; Liu, L.; Shan, H.; Lei, C.L.; Hui, D.S.C.; et al. Clinical Characteristics of Coronavirus Disease 2019 in China. N. Engl. J. Med. 2020, 382, 1708-1720. [CrossRef] [PubMed]

100. Garcia-Olivé, I.; Sintes, H.; Radua, J.; Abad Capa, J.; Rosell, A. D-dimer in patients infected with COVID-19 and suspected pulmonary embolism. Respir. Med. 2020, 169, 106023. [CrossRef]

101. Al-Samkari, H.; Karp Leaf, R.S.; Dzik, W.H.; Carlson, J.C.T.; Fogerty, A.E.; Waheed, A.; Goodarzi, K.; Bendapudi, P.K.; Bornikova, L.; Gupta, S.; et al. COVID-19 and coagulation: Bleeding and thrombotic manifestations of SARS-CoV-2 infection. Blood 2020, 136, 489-500. [CrossRef]

102. Wool, G.D.; Miller, J.L. The Impact of COVID-19 Disease on Platelets and Coagulation. Pathobiology 2021, 88, 15-27. [CrossRef] [PubMed]

103. Gershom, E.S.; Sutherland, M.R.; Lollar, P.; Pryzdial, E.L. Involvement of the contact phase and intrinsic pathway in herpes simplex virus-initiated plasma coagulation. J. Thromb. Haemost. 2010, 8, 1037-1043. [CrossRef] [PubMed]

104. Meini, S.; Zanichelli, A.; Sbrojavacca, R.; Iuri, F.; Roberts, A.T.; Suffritti, C.; Tascini, C. Understanding the Pathophysiology of COVID-19: Could the Contact System Be the Key? Front. Immunol. 2020, 11, 2014. [CrossRef]

105. Kannemeier, C.; Shibamiya, A.; Nakazawa, F.; Trusheim, H.; Ruppert, C.; Markart, P.; Song, Y.; Tzima, E.; Kennerknecht, E.; Niepmann, M.; et al. Extracellular RNA constitutes a natural procoagulant cofactor in blood coagulation. Proc. Natl. Acad. Sci. USA 2007, 104, 6388-6393. [CrossRef] [PubMed]

106. Naudin, C.; Burillo, E.; Blankenberg, S.; Butler, L.; Renné, T. Factor XII Contact Activation. Semin. Thromb. Hemost. 2017, 43, 814-826. [CrossRef] [PubMed] 
107. Verma, S.; Bednar, V.; Blount, A.; Hogue, B.G. Identification of functionally important negatively charged residues in the carboxy end of mouse hepatitis coronavirus A59 nucleocapsid protein. J. Virol. 2006, 80, 4344-4355. [CrossRef]

108. Huang, Z.; Ning, B.; Yang, H.S.; Youngquist, B.M.; Niu, A.; Lyon, C.J.; Beddingfield, B.J.; Fears, A.C.; Monk, C.H.; Murrell, A.E.; et al. Sensitive tracking of circulating viral RNA through all stages of SARS-CoV-2 infection. J. Clin. Investig. 2021, 131. [CrossRef]

109. Englert, H.; Rangaswamy, C.; Deppermann, C.; Sperhake, J.-P.; Krisp, C.; Schreier, D.; Gordon, E.; Konrath, S.; Haddad, M.; Pula, G.; et al. Defective NETs Clearance contributes to sustained FXII Activation in COVID-19-associated Pulmonary ThromboInflammation. bioRxiv 2020, arXiv:2020.12.29.424644.

110. Jin, X.; Duan, Y.; Bao, T.; Gu, J.; Chen, Y.; Li, Y.; Mao, S.; Chen, Y.; Xie, W. The values of coagulation function in COVID-19 patients. PLoS ONE 2020, 15, e0241329. [CrossRef]

111. Blasi, A.; von Meijenfeldt, F.A.; Adelmeijer, J.; Calvo, A.; Ibañez, C.; Perdomo, J.; Reverter, J.C.; Lisman, T. In vitro hypercoagulability and ongoing in vivo activation of coagulation and fibrinolysis in COVID-19 patients on anticoagulation. J. Thromb. Haemost. 2020, 18, 2646-2653. [CrossRef]

112. Tillman, B.; Gailani, D. Inhibition of Factors XI and XII for Prevention of Thrombosis Induced by Artificial Surfaces. Semin. Thromb. Hemost. 2018, 44, 60-69. [CrossRef] [PubMed]

113. Lippi, G.; Plebani, M.; Henry, B.M. Thrombocytopenia is associated with severe coronavirus disease 2019 (COVID-19) infections: A meta-analysis. Clin. Chim. Acta 2020, 506, 145-148. [CrossRef] [PubMed]

114. Thon, J.N.; Italiano, J.E. Platelet formation. Semin. Hematol. 2010, 47, 220-226. [CrossRef] [PubMed]

115. Bennett, J.S.; Kolodziej, M.A. Disorders of platelet function. Dis. Mon. 1992, 38, 577-631. [CrossRef]

116. Tao, L.; Zeng, Q.; Li, J.; Xu, M.; Wang, J.; Pan, Y.; Wang, H.; Tao, Q.; Chen, Y.; Peng, J.; et al. Platelet desialylation correlates with efficacy of first-line therapies for immune thrombocytopenia. J. Hematol. Oncol. 2017, 10, 46. [CrossRef]

117. Zhang, S.; Liu, Y.; Wang, X.; Yang, L.; Li, H.; Wang, Y.; Liu, M.; Zhao, X.; Xie, Y.; Yang, Y.; et al. SARS-CoV-2 binds platelet ACE2 to enhance thrombosis in COVID-19. J. Hematol. Oncol. 2020, 13, 120. [CrossRef] [PubMed]

118. Zaid, Y.; Senhaji, N.; Darif, Y.; Kojok, K.; Oudghiri, M.; Naya, A. Distinctive roles of PKC delta isozyme in platelet function. Curr. Res. Transl. Med. 2016, 64, 135-139. [CrossRef] [PubMed]

119. Comer, S.P.; Cullivan, S.; Szklanna, P.B.; Weiss, L.; Cullen, S.; Kelliher, S.; Smolenski, A.; Murphy, C.; Altaie, H.; Curran, J.; et al. COVID-19 induces a hyperactive phenotype in circulating platelets. PLoS Biol. 2021, 19, e3001109. [CrossRef]

120. Liu, Y.; Sun, W.; Guo, Y.; Chen, L.; Zhang, L.; Zhao, S.; Long, D.; Yu, L. Association between platelet parameters and mortality in coronavirus disease 2019: Retrospective cohort study. Platelets 2020, 31, 490-496. [CrossRef]

121. Handtke, S.; Thiele, T. Large and small platelets-(When) do they differ? J. Thromb. Haemost. 2020, 18, 1256-1267. [CrossRef] [PubMed]

122. Reddy, E.C.; Rand, M.L. Procoagulant Phosphatidylserine-Exposing Platelets in vitro and in vivo. Front. Cardiovasc. Med. 2020, 7, 15. [CrossRef]

123. Conti, P.; Ronconi, G.; Caraffa, A.; Gallenga, C.E.; Ross, R.; Frydas, I.; Kritas, S.K. Induction of pro-inflammatory cytokines (IL-1 and IL-6) and lung inflammation by Coronavirus-19 (COVI-19 or SARS-CoV-2): Anti-inflammatory strategies. J. Biol. Regul. Homeost. Agents 2020, 34, 327-331.

124. Hottz, E.D.; Azevedo-Quintanilha, I.G.; Palhinha, L.; Teixeira, L.; Barreto, E.A.; Pão, C.R.R.; Righy, C.; Franco, S.; Souza, T.M.L.; Kurtz, P.; et al. Platelet activation and platelet-monocyte aggregate formation trigger tissue factor expression in patients with severe COVID-19. Blood 2020, 136, 1330-1341. [CrossRef]

125. Manne, B.K.; Denorme, F.; Middleton, E.A.; Portier, I.; Rowley, J.W.; Stubben, C.; Petrey, A.C.; Tolley, N.D.; Guo, L.; Cody, M.; et al. Platelet gene expression and function in patients with COVID-19. Blood 2020, 136, 1317-1329. [CrossRef]

126. Neri, T.; Nieri, D.; Celi, A. P-selectin blockade in COVID-19-related ARDS. Am. J. Physiol. Lung Cell Mol. Physiol. 2020, 318, L1237-L1238. [CrossRef]

127. Bongiovanni, D.; Klug, M.; Lazareva, O.; Weidlich, S.; Biasi, M.; Ursu, S.; Warth, S.; Buske, C.; Lukas, M.; Spinner, C.D.; et al. SARS-CoV-2 infection is associated with a pro-thrombotic platelet phenotype. Cell Death Dis. 2021, 12, 50. [CrossRef] [PubMed]

128. Green, D. Coagulation cascade. Hemodial. Int. 2006, 10 (Suppl.2), S2-S4. [CrossRef] [PubMed]

129. Dunkelberger, J.R.; Song, W.-C. Complement and its role in innate and adaptive immune responses. Cell Res. 2010, 20, 34-50. [CrossRef] [PubMed]

130. Morgan, B.P.; Gasque, P. Extrahepatic complement biosynthesis: Where, when and why? Clin. Exp. Immunol. 1997, $107,1-7$. [CrossRef]

131. Lubbers, R.; van Essen, M.F.; van Kooten, C.; Trouw, L.A. Production of complement components by cells of the immune system. Clin. Exp. Immunol. 2017, 188, 183-194. [CrossRef]

132. Ghebrehiwet, B.; Silverberg, M.; Kaplan, A.P. Activation of the classical pathway of complement by Hageman factor fragment. J. Exp. Med. 1981, 153, 665-676. [CrossRef] [PubMed]

133. Krarup, A.; Wallis, R.; Presanis, J.S.; Gál, P.; Sim, R.B. Simultaneous activation of complement and coagulation by MBL-associated serine protease 2. PLoS ONE 2007, 2, e623. [CrossRef]

134. Ikeda, K.; Nagasawa, K.; Horiuchi, T.; Tsuru, T.; Nishizaka, H.; Niho, Y. C5a induces tissue factor activity on endothelial cells. Thromb. Haemost. 1997, 77, 394-398. [CrossRef]

135. Gao, T.; Hu, M.; Zhang, X.; Li, H.; Zhu, L.; Liu, H.; Dong, Q.; Zhang, Z.; Wang, Z.; Hu, Y.; et al. Highly pathogenic coronavirus N protein aggravates lung injury by MASP-2-mediated complement over-activation. medRxiv 2020. [CrossRef] 
136. Bumiller-Bini, V.; de Freitas Oliveira-Toré, C.; Carvalho, T.M.; Kretzschmar, G.C.; Gonçalves, L.B.; Alencar, N.M.; Gasparetto Filho, M.A.; Beltrame, M.H.; Winter Boldt, A.B. MASPs at the crossroad between the complement and the coagulation cascades-The case for COVID-19. Genet. Mol. Biol. 2021, 44, e20200199. [CrossRef] [PubMed]

137. Levi, M.; ten Cate, H.; van der Poll, T. Endothelium: Interface between coagulation and inflammation. Crit. Care Med. 2002, 30, S220-S224. [CrossRef] [PubMed]

138. Michiels, C. Endothelial cell functions. J. Cell. Physiol. 2003, 196, 430-443. [CrossRef]

139. Schouten, M.; Wiersinga, W.J.; Levi, M.; van der Poll, T. Inflammation, endothelium, and coagulation in sepsis. J. Leukoc. Biol. 2008, 83, 536-545. [CrossRef]

140. Giordo, R.; Paliogiannis, P.; Mangoni, A.A.; Pintus, G. SARS-CoV-2 and endothelial cell interaction in COVID-19: Molecular perspectives. Vasc. Biol. 2021, 3, R15-R23. [CrossRef] [PubMed]

141. Varga, Z.; Flammer, A.J.; Steiger, P.; Haberecker, M.; Andermatt, R.; Zinkernagel, A.S.; Mehra, M.R.; Schuepbach, R.A.; Ruschitzka, F.; Moch, H. Endothelial cell infection and endotheliitis in COVID-19. Lancet 2020, 395, 1417-1418. [CrossRef]

142. Huertas, A.; Montani, D.; Savale, L.; Pichon, J.; Tu, L.; Parent, F.; Guignabert, C.; Humbert, M. Endothelial cell dysfunction: A major player in SARS-CoV-2 infection (COVID-19)? Eur. Respir. J. 2020, 56. [CrossRef]

143. Wagner, D.D.; Bonfanti, R. von Willebrand factor and the endothelium. Mayo Clin. Proc. 1991, 66, 621-627. [CrossRef]

144. Ward, S.E.; Curley, G.F.; Lavin, M.; Fogarty, H.; Karampini, E.; McEvoy, N.L.; Clarke, J.; Boylan, M.; Alalqam, R.; Worrall, A.P.; et al. Von Willebrand factor propeptide in severe coronavirus disease 2019 (COVID-19): Evidence of acute and sustained endothelial cell activation. Br. J. Haematol. 2021, 192, 714-719. [CrossRef] [PubMed]

145. Stockschlaeder, M.; Schneppenheim, R.; Budde, U. Update on von Willebrand factor multimers: Focus on high-molecular-weight multimers and their role in hemostasis. Blood Coagul. Fibrinolysis 2014, 25, 206-216. [CrossRef] [PubMed]

146. Chen, J.; Chung, D.W. Inflammation, von Willebrand factor, and ADAMTS13. Blood 2018, 132, 141-147. [CrossRef] [PubMed]

147. Mancini, I.; Baronciani, L.; Artoni, A.; Colpani, P.; Biganzoli, M.; Cozzi, G.; Novembrino, C.; Boscolo Anzoletti, M.; De Zan, V.; Pagliari, M.T.; et al. The ADAMTS13-von Willebrand factor axis in COVID-19 patients. J. Thromb. Haemost. 2021, 19, 513-521. [CrossRef]

148. Bonetti, P.O.; Lerman, L.O.; Lerman, A. Endothelial dysfunction: A marker of atherosclerotic risk. Arterioscler. Thromb. Vasc. Biol. 2003, 23, 168-175. [CrossRef]

149. Davies, P.F.; Remuzzi, A.; Gordon, E.J.; Dewey, C.F., Jr.; Gimbrone, M.A., Jr. Turbulent fluid shear stress induces vascular endothelial cell turnover in vitro. Proc. Natl. Acad. Sci. USA 1986, 83, 2114-2117. [CrossRef] [PubMed]

150. Nelson, M.; Shi, D.; Gordon, M.; Chavda, Y.; Grimaldi, C.; Bajaj, T. Where There's Smoke, There's Fire: A Case Report of Turbulent Blood Flow in Lower Extremity Point-of-care Ultrasound in COVID-19. Clin. Pract. Cases Emerg. Med. 2021, 5, 30-34.

151. Kamel, M.H.; Yin, W.; Zavaro, C.; Francis, J.M.; Chitalia, V.C. Hyperthrombotic Milieu in COVID-19 Patients. Cells 2020, 9 , 2392. [CrossRef] [PubMed]

152. Merad, M.; Martin, J.C. Pathological inflammation in patients with COVID-19: A key role for monocytes and macrophages. Nat. Rev. Immunol. 2020, 20, 355-362. [CrossRef] [PubMed]

153. Skendros, P.; Mitsios, A.; Chrysanthopoulou, A.; Mastellos, D.C.; Metallidis, S.; Rafailidis, P.; Ntinopoulou, M.; Sertaridou, E.; Tsironidou, V.; Tsigalou, C.; et al. Complement and tissue factor-enriched neutrophil extracellular traps are key drivers in COVID-19 immunothrombosis. J. Clin. Investig. 2020, 130, 6151-6157. [CrossRef]

154. Cañas, C.A.; Cañas, F.; Bautista-Vargas, M.; Bonilla-Abadía, F. Role of Tissue Factor in the Pathogenesis of COVID-19 and the Possible Ways to Inhibit It. Clin. Appl. Thromb. Hemost. 2021, 27, 10760296211003983. [CrossRef] [PubMed]

155. McVey, J.H. Tissue factor pathway. Baillieres Clin. Haematol. 1994, 7, 469-484. [CrossRef]

156. Zhang, J.; Wu, H.; Yao, X.; Zhang, D.; Zhou, Y.; Fu, B.; Wang, W.; Li, H.; Wang, Z.; Hu, Z.; et al. Pyroptotic macrophages stimulate the SARS-CoV-2-associated cytokine storm. Cell. Mol. Immunol. 2021, 18, 1305-1307. [CrossRef] [PubMed]

157. Tay, M.Z.; Poh, C.M.; Rénia, L.; MacAry, P.A.; Ng, L.F.P. The trinity of COVID-19: Immunity, inflammation and intervention. Nat. Rev. Immunol. 2020, 20, 363-374. [CrossRef]

158. Abassi, Z.; Knaney, Y.; Karram, T.; Heyman, S.N. The Lung Macrophage in SARS-CoV-2 Infection: A Friend or a Foe? Front. Immunol. 2020, 11, 1312. [CrossRef]

159. Kasuga, Y.; Zhu, B.; Jang, K.-J.; Yoo, J.-S. Innate immune sensing of coronavirus and viral evasion strategies. Exp. Mol. Med. 2021, 53, 723-746. [CrossRef] [PubMed]

160. Wu, C.; Lu, W.; Zhang, Y.; Zhang, G.; Shi, X.; Hisada, Y.; Grover, S.P.; Zhang, X.; Li, L.; Xiang, B.; et al. Inflammasome Activation Triggers Blood Clotting and Host Death through Pyroptosis. Immunity 2019, 50, 1401-1411.e4. [CrossRef]

161. Pawlinski, R.; Wang, J.G.; Owens, A.P., 3rd; Williams, J.; Antoniak, S.; Tencati, M.; Luther, T.; Rowley, J.W.; Low, E.N.; Weyrich, A.S.; et al. Hematopoietic and nonhematopoietic cell tissue factor activates the coagulation cascade in endotoxemic mice. Blood 2010, 116, 806-814. [CrossRef]

162. Lillicrap, D. Disseminated intravascular coagulation in patients with 2019-nCoV pneumonia. J. Thromb. Haemost. 2020, 18, 786-787. [CrossRef] [PubMed]

163. Donia, A.; Bokhari, H. Apoptosis induced by SARS-CoV-2: Can we target it? Apoptosis 2021, 26, 7-8. [CrossRef]

164. Yang, A.; Chen, F.; He, C.; Zhou, J.; Lu, Y.; Dai, J.; Birge, R.B.; Wu, Y. The Procoagulant Activity of Apoptotic Cells Is Mediated by Interaction with Factor XII. Front. Immunol. 2017, 8, 1188. [CrossRef] 
165. Sprague, A.H.; Khalil, R.A. Inflammatory cytokines in vascular dysfunction and vascular disease. Biochem. Pharmacol. 2009, 78, 539-552. [CrossRef]

166. Goette, A.; Patscheke, M.; Henschke, F.; Hammwohner, M. COVID-19-Induced Cytokine Release Syndrome Associated with Pulmonary Vein Thromboses, Atrial Cardiomyopathy, and Arterial Intima Inflammation. TH Open 2020, 4, e271-e279. [CrossRef]

167. Veras, F.P.; Pontelli, M.C.; Silva, C.M.; Toller-Kawahisa, J.E.; de Lima, M.; Nascimento, D.C.; Schneider, A.H.; Caetité, D.; Tavares, L.A.; Paiva, I.M.; et al. SARS-CoV-2-triggered neutrophil extracellular traps mediate COVID-19 pathology. J. Exp. Med. 2020, 217, e20201129. [CrossRef] [PubMed]

168. Ng, H.; Havervall, S.; Rosell, A.; Aguilera, K.; Parv, K.; von Meijenfeldt, F.A.; Lisman, T.; Mackman, N.; Thålin, C.; Phillipson, M. Circulating Markers of Neutrophil Extracellular Traps Are of Prognostic Value in Patients With COVID-19. Arterioscler. Thromb. Vasc. Biol. 2021, 41, 988-994. [CrossRef]

169. Janiuk, K.; Jabłońska, E.; Garley, M. Significance of NETs Formation in COVID-19. Cells 2021, 10, 151. [CrossRef]

170. Zuo, Y.; Yalavarthi, S.; Shi, H.; Gockman, K.; Zuo, M.; Madison, J.A.; Blair, C.; Weber, A.; Barnes, B.J.; Egeblad, M.; et al. Neutrophil extracellular traps in COVID-19. JCI Insight 2020, 5, e138999.

171. Praetner, M.; Zuchtriegel, G.; Holzer, M.; Uhl, B.; Schaubächer, J.; Mittmann, L.; Fabritius, M.; Fürst, R.; Zahler, S.; Funken, D.; et al. Plasminogen Activator Inhibitor-1 Promotes Neutrophil Infiltration and Tissue Injury on Ischemia-Reperfusion. Arterioscler. Thromb. Vasc. Biol. 2018, 38, 829-842. [CrossRef] [PubMed]

172. Whyte, C.S.; Morrow, G.B.; Mitchell, J.L.; Chowdary, P.; Mutch, N.J. Fibrinolytic abnormalities in acute respiratory distress syndrome (ARDS) and versatility of thrombolytic drugs to treat COVID-19. J. Thromb. Haemost. 2020, 18, 1548-1555. [CrossRef] [PubMed]

173. Sillen, M.; Declerck, P.J. Targeting PAI-1 in Cardiovascular Disease: Structural Insights Into PAI-1 Functionality and Inhibition. Front. Cardiovasc. Med. 2020, 7, 622473. [CrossRef]

174. Whelihan, M.F.; Mann, K.G. The role of the red cell membrane in thrombin generation. Thromb. Res. 2013, 131, 377-382. [CrossRef] [PubMed]

175. Mackman, N. The red blood cell death receptor and thrombosis. J. Clin. Investig. 2018, 128, 3747-3749. [CrossRef] [PubMed]

176. Setty, B.N.; Rao, A.K.; Stuart, M.J. Thrombophilia in sickle cell disease: The red cell connection. Blood 2001, 98, 3228-3233. [CrossRef]

177. Horne, M.K., 3rd; Cullinane, A.M.; Merryman, P.K.; Hoddeson, E.K. The effect of red blood cells on thrombin generation. Br. J. Haematol. 2006, 133, 403-408. [CrossRef]

178. Sackner, M.A.; Adams, J.A. Endothelial pulsatile shear stress is a backstop for COVID-19. Emerg. Top. Life Sci. 2020, 4, 379-387. [CrossRef] [PubMed]

179. Tang, Y.; Liu, J.; Zhang, D.; Xu, Z.; Ji, J.; Wen, C. Cytokine Storm in COVID-19: The Current Evidence and Treatment Strategies. Front. Immunol. 2020, 11, 1708. [CrossRef] [PubMed]

180. Jose, R.J.; Manuel, A. COVID-19 cytokine storm: The interplay between inflammation and coagulation. Lancet. Respir. Med. 2020, 8, e46-e47. [CrossRef]

181. Castelli, V.; Cimini, A.; Ferri, C. Cytokine Storm in COVID-19: “When You Come Out of the Storm, You Won't Be the Same Person Who Walked in". Front. Immunol. 2020, 11, 2132. [CrossRef]

182. Mehta, P.; McAuley, D.F.; Brown, M.; Sanchez, E.; Tattersall, R.S.; Manson, J.J. COVID-19: Consider cytokine storm syndromes and immunosuppression. Lancet 2020, 395, 1033-1034. [CrossRef]

183. Goyal, A.; Prasad, R.; Goel, P.; Pal, A.; Prasad, S.; Rani, I. An Integrated Approach of the Potential Underlying Molecular Mechanistic Paradigms of SARS-CoV-2-Mediated Coagulopathy. Indian J. Clin. Biochem. 2021. [CrossRef] [PubMed]

184. Bhaskar, S.; Sinha, A.; Banach, M.; Mittoo, S.; Weissert, R.; Kass, J.S.; Rajagopal, S.; Pai, A.R.; Kutty, S. Cytokine Storm in COVID19-Immunopathological Mechanisms, Clinical Considerations, and Therapeutic Approaches: The REPROGRAM Consortium Position Paper. Front. Immunol. 2020, 11, 1648. [CrossRef] [PubMed]

185. Page, M.J.; Bester, J.; Pretorius, E. The inflammatory effects of TNF- $\alpha$ and complement component 3 on coagulation. Sci. Rep. 2018, 8, 1812. [CrossRef]

186. Bester, J.; Matshailwe, C.; Pretorius, E. Simultaneous presence of hypercoagulation and increased clot lysis time due to IL-1 $\beta$, IL-6 and IL-8. Cytokine 2018, 110, 237-242. [CrossRef] [PubMed]

187. Della-Torre, E.; Lanzillotta, M.; Campochiaro, C.; Cavalli, G.; De Luca, G.; Tomelleri, A.; Boffini, N.; De Lorenzo, R.; Ruggeri, A.; Rovere-Querini, P.; et al. Respiratory Impairment Predicts Response to IL-1 and IL-6 Blockade in COVID-19 Patients With Severe Pneumonia and Hyper-Inflammation. Front. Immunol. 2021, 12, 675678. [CrossRef]

188. Okabayashi, T.; Kariwa, H.; Yokota, S.; Iki, S.; Indoh, T.; Yokosawa, N.; Takashima, I.; Tsutsumi, H.; Fujii, N. Cytokine regulation in SARS coronavirus infection compared to other respiratory virus infections. J. Med. Virol. 2006, 78, 417-424. [CrossRef]

189. Yoshida, K.; Taga, T.; Saito, M.; Suematsu, S.; Kumanogoh, A.; Tanaka, T.; Fujiwara, H.; Hirata, M.; Yamagami, T.; Nakahata, T.; et al. Targeted disruption of gp130, a common signal transducer for the interleukin 6 family of cytokines, leads to myocardial and hematological disorders. Proc. Natl. Acad. Sci. USA 1996, 93, 407-411. [CrossRef]

190. Yoshimura, A.; Naka, T.; Kubo, M. SOCS proteins, cytokine signalling and immune regulation. Nat. Rev. Immunol. 2007, 7, 454-465. [CrossRef] [PubMed]

191. Schmitz, J.; Weissenbach, M.; Haan, S.; Heinrich, P.C.; Schaper, F. SOCS3 exerts its inhibitory function on interleukin-6 signal transduction through the SHP2 recruitment site of gp130. J. Biol. Chem. 2000, 275, 12848-12856. [CrossRef] 
192. Fang, S.; Liu, B.; Sun, Q.; Zhao, J.; Qi, H.; Li, Q. Platelet factor 4 inhibits IL-17/Stat3 pathway via upregulation of SOCS3 expression in melanoma. Inflammation 2014, 37, 1744-1750. [CrossRef]

193. Mosnier, L.O. Platelet factor 4 inhibits thrombomodulin-dependent activation of thrombin-activatable fibrinolysis inhibitor (TAFI) by thrombin. J. Biol. Chem. 2011, 286, 502-510. [CrossRef]

194. Martino, N.; Ramos, R.B.; Lu, S.; Leyden, K.; Tomaszek, L.; Jaitovich, A.; Vincent, P.A.; Adam, A.P. Endothelial SOCS3 maintains homeostasis and promotes survival in endotoxemic mice. bioRxiv 2020. [CrossRef]

195. Chen, Y.; Wang, J.; Liu, C.; Su, L.; Zhang, D.; Fan, J.; Yang, Y.; Xiao, M.; Xie, J.; Xu, Y.; et al. IP-10 and MCP-1 as biomarkers associated with disease severity of COVID-19. Mol. Med. 2020, 26, 97. [CrossRef] [PubMed]

196. Zheng, M.; Williams, E.P.; Malireddi, R.K.S.; Karki, R.; Banoth, B.; Burton, A.; Webby, R.; Channappanavar, R.; Jonsson, C.B.; Kanneganti, T.D. Impaired NLRP3 inflammasome activation/pyroptosis leads to robust inflammatory cell death via caspase8/RIPK3 during coronavirus infection. J. Biol. Chem. 2020, 295, 14040-14052. [CrossRef] [PubMed]

197. Burzynski, L.C.; Humphry, M.; Pyrillou, K.; Wiggins, K.A.; Chan, J.N.E.; Figg, N.; Kitt, L.L.; Summers, C.; Tatham, K.C.; Martin, P.B.; et al. The Coagulation and Immune Systems Are Directly Linked through the Activation of Interleukin-1 $\alpha$ by Thrombin. Immunity 2019, 50, 1033-1042.e6. [CrossRef] [PubMed]

198. Costela-Ruiz, V.J.; Illescas-Montes, R.; Puerta-Puerta, J.M.; Ruiz, C.; Melguizo-Rodríguez, L. SARS-CoV-2 infection: The role of cytokines in COVID-19 disease. Cytokine Growth Factor Rev. 2020, 54, 62-75. [CrossRef]

199. Scarpati, E.M.; Sadler, J.E. Regulation of endothelial cell coagulant properties. Modulation of tissue factor, plasminogen activator inhibitors, and thrombomodulin by phorbol 12-myristate 13-acetate and tumor necrosis factor. J. Biol. Chem. 1989, 264, 2070520713. [CrossRef]

200. Stearns-Kurosawa, D.J.; Kurosawa, S.; Mollica, J.S.; Ferrell, G.L.; Esmon, C.T. The endothelial cell protein C receptor augments protein C activation by the thrombin-thrombomodulin complex. Proc. Natl. Acad. Sci. USA 1996, 93, 10212-10216. [CrossRef]

201. Fukudome, K.; Esmon, C.T. Identification, cloning, and regulation of a novel endothelial cell protein C/activated protein C receptor. J. Biol. Chem. 1994, 269, 26486-26491. [CrossRef]

202. Raadsen, M.; Du Toit, J.; Langerak, T.; van Bussel, B.; van Gorp, E.; Goeijenbier, M. Thrombocytopenia in Virus Infections. J. Clin. Med. 2021, 10, 877. [CrossRef] [PubMed]

203. Gubernatorova, E.O.; Gorshkova, E.A.; Polinova, A.I.; Drutskaya, M.S. IL-6: Relevance for immunopathology of SARS-CoV-2. Cytokine Growth Factor Rev. 2020, 53, 13-24. [CrossRef]

204. van der Poll, T.; Levi, M.; Hack, C.E.; ten Cate, H.; van Deventer, S.J.; Eerenberg, A.J.; de Groot, E.R.; Jansen, J.; Gallati, H.; Büller, H.R.; et al. Elimination of interleukin 6 attenuates coagulation activation in experimental endotoxemia in chimpanzees. J. Exp. Med. 1994, 179, 1253-1259. [CrossRef] [PubMed]

205. Du, F.; Liu, B.; Zhang, S. COVID-19: The role of excessive cytokine release and potential ACE2 down-regulation in promoting hypercoagulable state associated with severe illness. J. Thromb. Thrombolysis 2021, 51, 313-329. [CrossRef]

206. Osnes, L.T.; Westvik, A.B.; Joø, G.B.; Okkenhaug, C.; Kierulf, P. Inhibition of IL-1 induced tissue factor (TF) synthesis and procoagulant activity (PCA) in purified human monocytes by IL-4, IL-10 and IL-13. Cytokine 1996, 8, 822-827. [CrossRef]

207. Qiao, J.; Wu, X.; Luo, Q.; Wei, G.; Xu, M.; Wu, Y.; Liu, Y.; Li, X.; Zi, J.; Ju, W.; et al. NLRP3 regulates platelet integrin $\alpha \mathrm{IIb} \beta 3$ outside-in signaling, hemostasis and arterial thrombosis. Haematologica 2018, 103, 1568-1576. [CrossRef]

208. Nosaka, M.; Ishida, Y.; Kimura, A.; Kuninaka, Y.; Inui, M.; Mukaida, N.; Kondo, T. Absence of IFN- $\gamma$ accelerates thrombus resolution through enhanced MMP-9 and VEGF expression in mice. J. Clin. Investig. 2011, 121, 2911-2920. [CrossRef]

209. Todoroki, N.; Watanabe, Y.; Akaike, T.; Katagiri, Y.; Tanoue, K.; Yamazaki, H.; Tsuji, T.; Toyoshima, S.; Osawa, T. Enhancement by IL-1 beta and IFN-gamma of platelet activation: Adhesion to leukocytes via GMP-140/PADGEM protein (CD62). Biochem. Biophys. Res. Commun. 1991, 179, 756-761. [CrossRef]

210. Takahashi, K.; Uwabe, Y.; Sawasaki, Y.; Kiguchi, T.; Nakamura, H.; Kashiwabara, K.; Yagyu, H.; Matsuoka, T. Increased secretion of urokinase-type plasminogen activator by human lung microvascular endothelial cells. Am. J. Physiol. 1998, 275, L47-L54. [CrossRef]

211. Page, M.J.; Bester, J.; Pretorius, E. Interleukin-12 and its procoagulant effect on erythrocytes, platelets and fibrin(ogen): The lesser known side of inflammation. Br. J. Haematol. 2018, 180, 110-117. [CrossRef]

212. Li, G.; Zhou, R.; Zhao, X.; Liu, R.; Ye, C. Correlation between the expression of IL-18 and deep venous thrombosis. Int. J. Mol. Med. 2018, 42, 2972.

213. Gedefaw, L.; Ullah, S.; Leung, P.H.M.; Cai, Y.; Yip, S.P.; Huang, C.L. Inflammasome Activation-Induced Hypercoagulopathy: Impact on Cardiovascular Dysfunction Triggered in COVID-19 Patients. Cells 2021, 10, 916. [CrossRef] [PubMed]

214. Xu, J.; Qu, D.; Esmon, N.L.; Esmon, C.T. Metalloproteolytic release of endothelial cell protein C receptor. J. Biol. Chem. 2000, 275, 6038-6044. [CrossRef] [PubMed]

215. Schmid, E.F.; Binder, K.; Grell, M.; Scheurich, P.; Pfizenmaier, K. Both tumor necrosis factor receptors, TNFR60 and TNFR80, are involved in signaling endothelial tissue factor expression by juxtacrine tumor necrosis factor alpha. Blood 1995, 86, 1836-1841. [CrossRef]

216. Martin, N.B.; Jamieson, A.; Tuffin, D.P. The effect of interleukin-4 on tumour necrosis factor-alpha induced expression of tissue factor and plasminogen activator inhibitor-1 in human umbilical vein endothelial cells. Thromb. Haemost. 1993, 70, 1037-1042. [CrossRef] 
217. Williams, M.A.; White, S.A.; Miller, J.J.; Toner, C.; Withington, S.; Newland, A.C.; Kelsey, S.M. Granulocyte-macrophage colonystimulating factor induces activation and restores respiratory burst activity in monocytes from septic patients. J. Infect. Dis. 1998, 177, 107-115. [CrossRef]

218. Bönig, H.; Burdach, S.; Göbel, U.; Nürnberger, W. Growth factors and hemostasis: Differential effects of GM-CSF and G-CSF on coagulation activation-laboratory and clinical evidence. Ann. Hematol. 2001, 80, 525-530. [CrossRef] [PubMed]

219. Schecter, A.D.; Rollins, B.J.; Zhang, Y.J.; Charo, I.F.; Fallon, J.T.; Rossikhina, M.; Giesen, P.L.; Nemerson, Y.; Taubman, M.B. Tissue factor is induced by monocyte chemoattractant protein-1 in human aortic smooth muscle and THP-1 cells. J. Biol. Chem. 1997, 272, 28568-28573. [CrossRef] [PubMed]

220. Naing, A.; Infante, J.R.; Papadopoulos, K.P.; Chan, I.H.; Shen, C.; Ratti, N.P.; Rojo, B.; Autio, K.A.; Wong, D.J.; Patel, M.R.; et al. PEGylated IL-10 (Pegilodecakin) Induces Systemic Immune Activation, CD8 ${ }^{+} \mathrm{T}$ Cell Invigoration and Polyclonal T Cell Expansion in Cancer Patients. Cancer Cell 2018, 34, 775-791.e3. [CrossRef]

221. Naing, A.; Papadopoulos, K.P.; Autio, K.A.; Ott, P.A.; Patel, M.R.; Wong, D.J.; Falchook, G.S.; Pant, S.; Whiteside, M.; Rasco, D.R.; et al. Safety, Antitumor Activity, and Immune Activation of Pegylated Recombinant Human Interleukin-10 (AM0010) in Patients With Advanced Solid Tumors. J. Clin. Oncol. 2016, 34, 3562-3569. [CrossRef] [PubMed]

222. Lu, L.; Zhang, H.; Dauphars, D.J.; He, Y.W. A Potential Role of Interleukin 10 in COVID-19 Pathogenesis. Trends Immunol. 2021, 42, 3-5. [CrossRef] [PubMed]

223. Ding, P.; Zhang, S.; Yu, M.; Feng, Y.; Long, Q.; Yang, H.; Li, J.; Wang, M. IL-17A promotes the formation of deep vein thrombosis in a mouse model. Int. Immunopharmacol. 2018, 57, 132-138. [CrossRef]

224. Guo, T.; Fan, Y.; Chen, M.; Wu, X.; Zhang, L.; He, T.; Wang, H.; Wan, J.; Wang, X.; Lu, Z. Cardiovascular Implications of Fatal Outcomes of Patients With Coronavirus Disease 2019 (COVID-19). JAMA Cardiol. 2020, 5, 811-818. [CrossRef] [PubMed]

225. Yang, J.; Zheng, Y.; Gou, X.; Pu, K.; Chen, Z.; Guo, Q.; Ji, R.; Wang, H.; Wang, Y.; Zhou, Y. Prevalence of comorbidities and its effects in patients infected with SARS-CoV-2: A systematic review and meta-analysis. Int. J. Infect. Dis. 2020, 94, 91-95. [CrossRef]

226. Li, B.; Yang, J.; Zhao, F.; Zhi, L.; Wang, X.; Liu, L.; Bi, Z.; Zhao, Y. Prevalence and impact of cardiovascular metabolic diseases on COVID-19 in China. Clin. Res. Cardiol. 2020, 109, 531-538. [CrossRef]

227. Zhou, F.; Yu, T.; Du, R.; Fan, G.; Liu, Y.; Liu, Z.; Xiang, J.; Wang, Y.; Song, B.; Gu, X.; et al. Clinical course and risk factors for mortality of adult inpatients with COVID-19 in Wuhan, China: A retrospective cohort study. Lancet 2020, 395, 1054-1062. [CrossRef]

228. Kurz, D.J.; Eberli, F.R. Cardiovascular aspects of COVID-19. Swiss Med. Wkly. 2020, 150, w20417.

229. Touch, S.; Assmann, K.E.; Aron-Wisnewsky, J.; Marquet, F.; Rouault, C.; Fradet, M.; Mosbah, H.; Consortium, M.; Isnard, R.; Helft, G.; et al. Mucosal-associated invariant T (MAIT) cells are depleted and prone to apoptosis in cardiometabolic disorders. FASEB J. 2018, 32, 5078-5089. [CrossRef] [PubMed]

230. Parrot, T.; Gorin, J.-B.; Ponzetta, A.; Maleki, K.T.; Kammann, T.; Emgård, J.; Perez-Potti, A.; Sekine, T.; Rivera-Ballesteros, O.; Gredmark-Russ, S.; et al. MAIT cell activation and dynamics associated with COVID-19 disease severity. Sci. Immunol. 2020, 5, eabe1670. [CrossRef]

231. Ahmed, F.; Jo, D.-H.; Lee, S.-H. Can Natural Killer Cells Be a Principal Player in Anti-SARS-CoV-2 Immunity? Front. Immunol. 2020, 11, 3246. [CrossRef]

232. Kusnadi, A.; Ramírez-Suástegui, C.; Fajardo, V.; Chee, S.J.; Meckiff, B.J.; Simon, H.; Pelosi, E.; Seumois, G.; Ay, F.; Vijayanand, P.; et al. Severely ill COVID-19 patients display impaired exhaustion features in SARS-CoV-2-reactive CD8 ${ }^{+} \mathrm{T}$ cells. Sci. Immunol. 2021, 6, eabe4782. [CrossRef] [PubMed]

233. Gronewold, J.; Engels, M.; van de Velde, S.; Cudjoe, T.K.M.; Duman, E.E.; Jokisch, M.; Kleinschnitz, C.; Lauterbach, K.; Erbel, R.; Jöckel, K.H.; et al. Effects of Life Events and Social Isolation on Stroke and Coronary Heart Disease. Stroke 2021, 52, 735-747. [CrossRef]

234. Muhammad, D.G.; Abubakar, I.A. COVID-19 lockdown may increase cardiovascular disease risk factors. Egypt. Heart J. 2021, 73, 2. [CrossRef]

235. Adu-Amankwaah, J.; Mprah, R.; Adekunle, A.O.; Ndzie Noah, M.L.; Adzika, G.K.; Machuki, J.O.; Sun, H. The cardiovascular aspect of COVID-19. Ann. Med. 2021, 53, 227-236. [CrossRef] [PubMed]

236. Bailey, A.L.; Dmytrenko, O.; Greenberg, L.; Bredemeyer, A.L.; Ma, P.; Liu, J.; Penna, V.; Winkler, E.S.; Sviben, S.; Brooks, E.; et al. SARS-CoV-2 Infects Human Engineered Heart Tissues and Models COVID-19 Myocarditis. JACC Basic Transl. Sci. 2021, 6, 331-345. [CrossRef]

237. Bansal, A.; Kumar, A.; Patel, D.; Puri, R.; Kalra, A.; Kapadia, S.R.; Reed, G.W. Meta-analysis Comparing Outcomes in Patients With and Without Cardiac Injury and Coronavirus Disease 2019 (COVID 19). Am. J. Cardiol. 2021, 141, 140-146. [CrossRef] [PubMed]

238. Fu, L.; Liu, X.; Su, Y.; Ma, J.; Hong, K. Prevalence and impact of cardiac injury on COVID-19: A systematic review and meta-analysis. Clin. Cardiol. 2021, 44, 276-283. [CrossRef]

239. Mills, R.J.; Humphrey, S.J.; Fortuna, P.R.J.; Lor, M.; Foster, S.R.; Quaife-Ryan, G.A.; Johnston, R.L.; Dumenil, T.; Bishop, C.; Rudraraju, R.; et al. BET inhibition blocks inflammation-induced cardiac dysfunction and SARS-CoV-2 infection. Cell 2021, 184, 2167-2182.e22. [CrossRef] [PubMed] 
240. Driggin, E.; Madhavan, M.V.; Bikdeli, B.; Chuich, T.; Laracy, J.; Biondi-Zoccai, G.; Brown, T.S.; Der Nigoghossian, C.; Zidar, D.A.; Haythe, J.; et al. Cardiovascular Considerations for Patients, Health Care Workers, and Health Systems During the COVID-19 Pandemic. J. Am. Coll. Cardiol. 2020, 75, 2352-2371. [CrossRef]

241. Clerkin, K.J.; Fried, J.A.; Raikhelkar, J.; Sayer, G.; Griffin, J.M.; Masoumi, A.; Jain, S.S.; Burkhoff, D.; Kumaraiah, D.; Rabbani, L.; et al. COVID-19 and Cardiovascular Disease. Circulation 2020, 141, 1648-1655. [CrossRef] [PubMed]

242. Gerges Harb, J.; Noureldine, H.A.; Chedid, G.; Eldine, M.N.; Abdallah, D.A.; Chedid, N.F.; Nour-Eldine, W. SARS, MERS and COVID-19: Clinical manifestations and organ-system complications: A mini review. Pathog. Dis. 2020, 78, ftaa033. [CrossRef] [PubMed]

243. Sultanian, P.; Lundgren, P.; Strömsöe, A.; Aune, S.; Bergström, G.; Hagberg, E.; Hollenberg, J.; Lindqvist, J.; Djärv, T.; Castelheim, A.; et al. Cardiac arrest in COVID-19: Characteristics and outcomes of in- and out-of-hospital cardiac arrest. A report from the Swedish Registry for Cardiopulmonary Resuscitation. Eur. Heart J. 2021, 42, 1094-1106. [CrossRef]

244. Riphagen, S.; Gomez, X.; Gonzalez-Martinez, C.; Wilkinson, N.; Theocharis, P. Hyperinflammatory shock in children during COVID-19 pandemic. Lancet 2020, 395, 1607-1608. [CrossRef]

245. Verdoni, L.; Mazza, A.; Gervasoni, A.; Martelli, L.; Ruggeri, M.; Ciuffreda, M.; Bonanomi, E.; D’Antiga, L. An outbreak of severe Kawasaki-like disease at the Italian epicentre of the SARS-CoV-2 epidemic: An observational cohort study. Lancet 2020, 395, 1771-1778. [CrossRef]

246. Inciardi, R.M.; Lupi, L.; Zaccone, G.; Italia, L.; Raffo, M.; Tomasoni, D.; Cani, D.S.; Cerini, M.; Farina, D.; Gavazzi, E.; et al. Cardiac Involvement in a Patient With Coronavirus Disease 2019 (COVID-19). JAMA Cardiol. 2020, 5, 819-824. [CrossRef]

247. Kotecha, T.; Knight, D.S.; Razvi, Y.; Kumar, K.; Vimalesvaran, K.; Thornton, G.; Patel, R.; Chacko, L.; Brown, J.T.; Coyle, C.; et al. Patterns of myocardial injury in recovered troponin-positive COVID-19 patients assessed by cardiovascular magnetic resonance. Eur. Heart J. 2021, 42, 1866-1878. [CrossRef]

248. Liu, Y.; Sawalha, A.H.; Lu, Q. COVID-19 and autoimmune diseases. Curr. Opin. Rheumatol. 2021, 33, 155-162. [CrossRef]

249. Talotta, R. Do COVID-19 RNA-based vaccines put at risk of immune-mediated diseases? In reply to "potential antigenic crossreactivity between SARS-CoV-2 and human tissue with a possible link to an increase in autoimmune diseases". Clin. Immunol. 2021, 224, 108665. [CrossRef]

250. Su, J.R.; McNeil, M.M.; Welsh, K.J.; Marquez, P.L.; Ng, C.; Yan, M.; Cano, M.V. Myopericarditis after vaccination, Vaccine Adverse Event Reporting System (VAERS), 1990-2018. Vaccine 2021, 39, 839-845. [CrossRef]

251. Polack, F.P.; Thomas, S.J.; Kitchin, N.; Absalon, J.; Gurtman, A.; Lockhart, S.; Perez, J.L.; Pérez Marc, G.; Moreira, E.D.; Zerbini, C.; et al. Safety and Efficacy of the BNT162b2 mRNA Covid-19 Vaccine. N. Engl. J. Med. 2020, 383, 2603-2615. [CrossRef]

252. Bakhshandeh, B.; Sorboni, S.G.; Javanmard, A.-R.; Mottaghi, S.S.; Mehrabi, M.-R.; Sorouri, F.; Abbasi, A.; Jahanafrooz, Z. Variants in ACE2; potential influences on virus infection and COVID-19 severity. Infect. Genet. Evol. 2021, 90, 104773. [CrossRef]

253. Manning, J.T.; Fink, B. Sex differences in the relationship between digit ratio (2D:4D) and national case fatality rates for COVID-19: A reply to Sahin (2020). Early Hum. Dev. 2020, 148, 105120. [CrossRef] [PubMed]

254. Wu, Y.; Feng, Z.; Li, P.; Yu, Q. Relationship between ABO blood group distribution and clinical characteristics in patients with COVID-19. Clin. Chim. Acta 2020, 509, 220-223. [CrossRef]

255. Nguyen, A.; David, J.K.; Maden, S.K.; Wood, M.A.; Weeder, B.R.; Nellore, A.; Thompson, R.F. Human Leukocyte Antigen Susceptibility Map for Severe Acute Respiratory Syndrome Coronavirus 2. J. Virol. 2020, 94. [CrossRef]

256. Lucas, C.; Klein, J.; Sundaram, M.E.; Liu, F.; Wong, P.; Silva, J.; Mao, T.; Oh, J.E.; Mohanty, S.; Huang, J.; et al. Delayed production of neutralizing antibodies correlates with fatal COVID-19. Nat. Med. 2021. [CrossRef]

257. Lau, S.Y.; Wang, P.; Mok, B.W.; Zhang, A.J.; Chu, H.; Lee, A.C.; Deng, S.; Chen, P.; Chan, K.H.; Song, W.; et al. Attenuated SARS-CoV-2 variants with deletions at the S1/S2 junction. Emerg. Microbes Infect. 2020, 9, 837-842. [CrossRef] [PubMed]

258. Mayoral, E.P.-C.; Hernández-Huerta, M.T.; Mayoral, L.P.-C.; Matias-Cervantes, C.A.; Mayoral-Andrade, G.; Barrios, L.; Ángel, L.; Pérez-Campos, E. Factors related to asymptomatic or severe COVID-19 infection. Med. Hypotheses 2020, 144, 110296. [CrossRef]

259. Muñoz-Fontela, C.; Dowling, W.E.; Funnell, S.G.P.; Gsell, P.-S.; Riveros-Balta, A.X.; Albrecht, R.A.; Andersen, H.; Baric, R.S.; Carroll, M.W.; Cavaleri, M.; et al. Animal models for COVID-19. Nature 2020, 586, 509-515. [CrossRef]

260. Monteil, V.; Kwon, H.; Prado, P.; Hagelkrüys, A.; Wimmer, R.A.; Stahl, M.; Leopoldi, A.; Garreta, E.; Del Pozo, C.H.; Prosper, F.; et al. Inhibition of SARS-CoV-2 Infections in Engineered Human Tissues Using Clinical-Grade Soluble Human ACE2. Cell 2020, 181, 905-913.e7. [CrossRef]

261. Wong, C.K.; Luk, H.K.; Lai, W.H.; Lau, Y.M.; Zhang, R.R.; Wong, A.C.; Lo, G.C.; Chan, K.H.; Hung, I.F.; Tse, H.F.; et al. HumanInduced Pluripotent Stem Cell-Derived Cardiomyocytes Platform to Study SARS-CoV-2 Related Myocardial Injury. Circ. J. 2020, 84, 2027-2031. [CrossRef]

262. Kim, Y.S.; Lee, S.Y.; Yoon, J.W.; Kim, D.; Yu, S.; Kim, J.S.; Kim, J.H. Cardiotoxicity induced by the combination therapy of chloroquine and azithromycin in human embryonic stem cell-derived cardiomyocytes. BMB Rep. 2020, 53, 545-550. [CrossRef]

263. Morgan, J.P. Use of the Ferret in Cardiovascular Research. In Biology and Diseases of the Ferret; Wiley: Hoboken, NJ, USA, 2014; pp. 653-663.

264. Goineau, S.; Pape, D.; Guillo, P.; Ramée, M.P.; Bellissant, E.; Goineau, S.; Pape, D.; Guillo, P.; Ramée, M.P.; Bellissant, E. Hemodynamic and histomorphometric characteristics of dilated cardiomyopathy of Syrian hamsters (Bio TO-2 strain). Can. J. Physiol. Pharmacol. 2001, 79, 329-337. [CrossRef] [PubMed] 
265. Cox, L.; Olivier, M.; Spradling-Reeves, K.; Karere, G.M.; Comuzzie, A.G.; VandeBerg, J.L. Nonhuman Primates and Translational Research-Cardiovascular Disease. ILAR J. 2017, 58, 235-250. [CrossRef] [PubMed]

266. Heegaard, P.M.H.; Sturek, M.; Alloosh, M.; Belsham, G.J. Animal Models for COVID-19: More to the Picture Than ACE2, Rodents, Ferrets, and Non-human Primates. A Case for Porcine Respiratory Coronavirus and the Obese Ossabaw Pig. Front. Microbiol. 2020, 11, 573756. [CrossRef] [PubMed]

267. Gordon, C.J.; Tchesnokov, E.P.; Woolner, E.; Perry, J.K.; Feng, J.Y.; Porter, D.P.; Götte, M. Remdesivir is a direct-acting antiviral that inhibits RNA-dependent RNA polymerase from severe acute respiratory syndrome coronavirus 2 with high potency. J. Biol. Chem. 2020, 295, 6785-6797. [CrossRef]

268. Alhazzani, W.; Møller, M.H.; Arabi, Y.M.; Loeb, M.; Gong, M.N.; Fan, E.; Oczkowski, S.; Levy, M.M.; Derde, L.; Dzierba, A.; et al. Surviving Sepsis Campaign: Guidelines on the management of critically ill adults with Coronavirus Disease 2019 (COVID-19). Intensive Care Med. 2020, 46, 854-887. [CrossRef] [PubMed]

269. Xu, X.; Han, M.; Li, T.; Sun, W.; Wang, D.; Fu, B.; Zhou, Y.; Zheng, X.; Yang, Y.; Li, X.; et al. Effective treatment of severe COVID-19 patients with tocilizumab. Proc. Natl. Acad. Sci. USA 2020, 117, 10970-10975. [CrossRef] [PubMed]

270. Gracia-Hernandez, M.; Sotomayor, E.M.; Villagra, A. Targeting Macrophages as a Therapeutic Option in Coronavirus Disease 2019. Front. Pharmacol. 2020, 11, 577571. [CrossRef] [PubMed]

271. Dondorp, A.M.; Hayat, M.; Aryal, D.; Beane, A.; Schultz, M.J. Respiratory Support in COVID-19 Patients, with a Focus on Resource-Limited Settings. Am. J. Trop. Med. Hyg. 2020, 102, 1191-1197. [CrossRef]

272. Hajra, A.; Mathai, S.V.; Ball, S.; Bandyopadhyay, D.; Veyseh, M.; Chakraborty, S.; Lavie, C.J.; Aronow, W.S. Management of Thrombotic Complications in COVID-19: An Update. Drugs 2020, 80, 1553-1562. [CrossRef] [PubMed]

273. Wang, J.; Hajizadeh, N.; Moore, E.E.; McIntyre, R.C.; Moore, P.; Veress, L.A.; Yaffe, M.B.; Moore, H.B.; Barrett, C.D. Tissue plasminogen activator (tPA) treatment for COVID-19 associated acute respiratory distress syndrome (ARDS): A case series. $J$. Thromb. Haemost. 2020, 18, 1752-1755. [CrossRef] [PubMed]

274. Kluge, S.; Janssens, U.; Welte, T.; Weber-Carstens, S.; Marx, G.; Karagiannidis, C. German recommendations for critically ill patients with COVID-19. Med. Klin. Intensivmed. Notf. 2020, 115, 111-114. [CrossRef] [PubMed] 